\title{
THE SHARING ECONOMY MEETS THE SHERMAN ACT: IS UBER A FIRM, A CARTEL, OR SOMETHING IN BETWEEN?
}

\author{
Mark Anderson and Max Huffman*
}

The sharing economy is a new industrial structure that is made possible by instantaneous internet communication and changes in the life, work, and purchasing habits of individual entrepreneurs and consumers. Antitrust law is an economic regulatory scheme dating back to 1890 in the United States that is designed to address centrally controlled concentrations of economic power and the threats that those concentrations pose to consumer interests and economic efficiency. In order to accommodate a modern enterprise structure in which thousands or millions of independent contractors join forces to provide a service by agreement among themselves, antitrust law requires re-envisioning and careful application. The success of Uber, Airbnb, and other sharing economy firms, and the consumer benefits that those firms promise, show both how difficult and how important that re-envisioning can be.

I. Introduction 861

II. Sharing Economy .............................................. 864

A. Defining the Sharing Economy ......................... 864

1. Sharing Economy Characteristics ................ 868

a. Seven Defining Factors ......................... 868

\footnotetext{
* Mark Anderson is a Professor of Law at the University of Idaho College of Law; Max Huffman is a Professor of Law at the Indiana University Robert H. McKinney School of Law. This article benefitted from colloquia at the University of Idaho College of Law and the Indiana University Robert H. McKinney School of Law, as well as specific comments and suggestions by Professor Benjamin Cover, Professor Nicholas Georgakopoulos, Professor Julian Nowag, Professor Nic Terry, and Michael Wilson. Susan deMaine provided expert library assistance and Allison Skimehorn provided research assistance. The authors particularly thank James Malmo, Darren Pouliot, and Elizabeth Brasher and their colleagues at the Columbia Business Law Review for excellent and professional editing assistance.
} 
b. Nomenclature 870

2. Regulatory Disruption and Regulatory Arbitrage. 870

3. Features of Leading Sharing Economy Enterprises 873

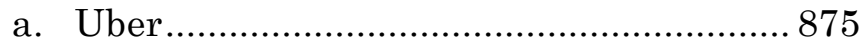

b. Airbnb .................................................... 878

c. Other Examples....................................... 879

B. Economics of the Sharing Economy................... 881

1. Efficiencies in the Sharing Economy............. 882

2. Both Centralized and Competitive ............... 883

3. Disrupting the Coasean Firm ....................... 884

III. Sherman Act Structure........................................... 886

A. The Agreement Requirement............................ 888

B. The Unreasonableness Requirement................. 890

1. Defining the Categorical Prohibition of Per Se

Rules. 891

2. Reducing the Number of Per Se Rules ......... 893

3. The Rule of Reason: Fast and Slow .............. 894

IV. Applying the Sherman Act to the Sharing Economy

A. Agreement Analysis ....................................... 899

1. Types of Sharing Economy Agreements....... 900

2. Horizontal Agreements Among Suppliers?... 901

a. Vertical Restrictions on Distribution ...... 902

b. Membership Organizations..................... 904

c. Joint Ventures ........................................ 905

d. Joint Sales Agencies .................................906

B. Is the Uber Arrangement Per Se Illegal? ........... 907

1. The Scope of the Per Se Rule ....................... 908

2. Broadcast Music, Inc. v. CBS ...................... 910

3. The Ancillarity Doctrine .............................. 911

4. Fast Sharing Economy Transactions Without Price Fixing

C. If the Uber Arrangement Is Not Per Se Illegal, Who Bears What Burdens Under the Rule of Reason?

V. Lessons for the Structure of a Sharing Economy Enterprise 
A. Diagramming Section 1 Conduct 917

1. X-Axis: Degree of Coordination 919

2. Y-Axis: Sharing of Risk 921

3. The Line $(\mathrm{X}, \mathrm{Y})=0$ to $(\mathrm{X}, \mathrm{Y}) \rightarrow \infty$ : Perfect Competition to Single Entity 923

B. Graphing Exemplar Sharing Economy Enterprises. 924

1. TaskRabbit................................................ 927

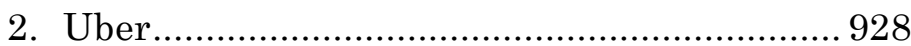

3. Airbnb ...................................................... 930

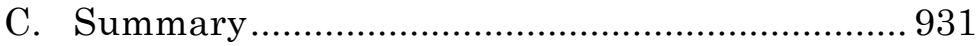

VI. Conclusion 932

\section{INTRODUCTION}

The sharing economy is a disruptive force challenging a wide range of legal and institutional structures. Sharing economy platform companies like Uber and Airbnb connect thousands of suppliers with millions of consumers every day. They do this using instantaneous communication and massive information sorting technology to coordinate the actions of suppliers and match them with consumers. In doing so, these platform companies have altered the basic conception of what constitutes a business firm. The resulting effect on antitrust law and policy is ambiguous, with conflict between apparent antitrust law concerns and evidence of massive consumer benefits. 1

Antitrust law has evolved over more than a century to regulate a marketplace occupied by firms. It uses a complex set of rules to assess the economic effects of agreements between firms, but leaves conduct within a firm subject to little scrutiny. In a traditional firm, owners contribute capital, managers make business decisions, and employees implement those

1 According to one study, "consumers always benefit from collaborative consumption.” Saif Benjaafar et al., Peer-to-Peer Product Sharing: Implications for Ownership, Usage, and Social Welfare in the Sharing Economy 3 (Oct. 6 2015) (unpublished manuscript) (on file with SSRN). 
decisions. The sharing economy confronts antitrust law by disaggregating the roles usually played by actors within a firm. In the sharing economy, workers provide much of the capital. 2 For example, Uber does not own a vast fleet of cars; its drivers supply the cars. The workers can be subject to substantial control by the managers of the platform, but are not treated as employees. This disaggregation takes activities that would usually be subject to little antitrust scrutiny because they are within a firm and subjects them to significantly greater antitrust scrutiny. Unthinking application of antitrust principles developed for the traditional firm to the reconfigured economic structures of the sharing economy is inappropriate.

Suppliers in a sharing economy enterprise reach agreements with the platform company about the company's terms of service. For example, sharing economy platforms nearly always include systems for making and receiving payment, impose requirements for suppliers' relationships with consumers, and establish a means for consumer reviews. Other terms that are not as ubiquitous also exist. Some sharing economy enterprises include agreements between suppliers and the platform on the price to be charged. Some terms are competitively neutral or procompetitive. Others, particularly including agreements on price, are typically considered matters of substantial antitrust concern.

Traditional black-letter antitrust law suggests alternative approaches to how courts should treat a sharing economy enterprise. One approach is to consider the agreements between suppliers and the platform to be "vertical agreements" subject to a fairly lenient "rule of reason." Another approach is to treat the agreements as a "hub-and-spoke" conspiracy, reflecting a "horizontal agreement" among suppliers to the enterprise orchestrated by the platform. ${ }^{3}$ If a horizontal agreement is

2 One study concludes that this operates to the benefit of below-median-income individuals, who are among the suppliers on sharing economy platforms. See Samuel Fraiberger \& Arun Sundararajan, Peer-to-Peer Rental Markets in the Sharing Economy 4 (Sept. 10, 2017) (unpublished manuscript) (on file with SSRN).

3 See Julian Nowag, The UBER-Cartel? UBER Between Labour and Competition Law, LUND EU L. REV., Fall 2016, at 94, 97, 
found, it will be subject to varying treatment depending on the level of competitive sensitivity. Agreements on price-one of the most competitively sensitive terms-may even be automatically illegal. This exact question is currently before a district court in New York in consumer antitrust litigation against Uber.

This Article analyzes these alternative approaches, taking account of leading authorities interpreting section 1 of the Sherman Act, to conclude that a "quick look" rule of reason is the most appropriate line of analysis for sharing economy terms of service that present the greatest antitrust concerns. Under the quick look approach, a plaintiff can easily demonstrate the likelihood of anticompetitive effects and the defendant must offer a procompetitive justification. "Per se" invalidity remains possible but, in light of the unique benefits that sharing economy enterprises produce, is unlikely. Terms of service that touch on matters less competitively sensitive, including payment terms and quality requirements for products and services, will likely receive a full-blown rule of reason analysis and be upheld under antitrust laws.

Beyond analyzing the application of traditional antitrust principles to the sharing economy, this Article advocates a new approach. Unique to a sharing economy enterprise is a structure that resembles a single entity, yet remains a set of agreements among highly diffuse individual actors. This structure results in a sharing of economic risks among the participants in the sharing economy enterprise, which can incentivize efficiencies in operation that ordinarily are found in a single entity. This Article concludes that those efficiencies can overcome anticompetitive concerns about coordination on competitively sensitive matters. The resulting approach, represented by graphing the degree of risk-sharing in relation to the degree of coordination, promises a superior analysis for the application of section 1 of the Sherman Act to the sharing economy.

[https://perma.cc/BW37-6E8D]; see generally Barak Orbach, Hub-andSpoke Conspiracies, AnTitrust Source, Apr. 2016, at 1. 
Part II of this Article defines the sharing economy and sets forth the economic analysis that separates it from the traditional economy. Part III examines the antitrust principles under section 1 of the Sherman Act that assess agreements between firms. Part IV analyzes the application of these principles to the sharing economy. Finally, Part V argues that these principles should be altered for application to the sharing economy. Specifically, Part V argues that the categorical rules developed under section 1 should yield to an approach based more on matters of degree. And in applying this matter of degree approach, increased levels of coordination between actors in the sharing economy should be allowed under section 1 because those actors share more economic risk with each other than do actors in the traditional economy.

\section{SHARING ECONOMY}

This Part explains the sharing economy in terms that prepare for an analysis of the antitrust consequences of sharing economy firms. Subpart A defines the sharing economy, sharing economy firms, and sharing economy enterprises by reference both to historic analogs and to information-age realities. Subpart B discusses the economics of the sharing economy, the four efficiencies that sharing economy firms all leverage to varying extents, and the complementary ideas of regulatory disruption and regulatory arbitrage. Subpart $\mathrm{C}$ examines the structure and operation of sharing economy firms with particular emphasis on Uber, Airbnb, Lyft, Couchsurfing, and TaskRabbit.

\section{A. Defining the Sharing Economy}

The sharing economy leverages resource cross-utilization. ${ }^{4}$ Terminology varies; the sharing economy has been denoted

\footnotetext{
4 See Akanksha Srivastava, Sharing Economy: Old World Renting Meets New World Technology, LinkEDIN (July 5, 2016), https://www.linkedin.com/pulse/sharing-economy-old-world-renting-meetsnew-akanksha-srivastava [perma.cc/JK2U-GHBU]. A substantial amount of the information and analysis governing the sharing economy is found online in the form of sophisticated news articles from outlets including
} 
"the peer-to-peer economy," "collaborative consumption," "gig economy," and "the access economy," among other terms. 5 All terms describe a "decentralized model whereby two individuals interact to buy or sell goods and services directly with each other, without intermediation by a third-party, or without the use of a company of business. The buyer and the seller transact directly with each other." 6 Consistent with the November 2016 Federal Trade Commission Staff Report, "The Sharing Economy: Issues Facing Platforms, Participants, and Regulators," (the "FTC Report"), this Article adopts use of the term "sharing economy."7

Some debate exists regarding the proper reach of the phrase "sharing economy." More than one author questions entirely whether it is appropriate in the context of for-fee exchanges. 8 The modern use of the phrase likely dates to 2007,9 but is most frequently identified with a 2008 Creative Commons license text by Lawrence Lessig. ${ }^{10}$ Lessig defined the sharing economy in juxtaposition to a commercial internetbased economy. "[N]ot only is money not helpful. In many

CNET and the Huffington Post, as well as in the blogosphere. By necessity, then, this Article includes more cites to blogs and other internet sources than is usual for legal scholarship.

5 Rashmi Dyal-Chand, Regulating Sharing: The Sharing Economy As an Alternative Capitalist System, 90 Tul. L. REv. 241, 243 (2015); FED. Trade Comm'n, The "Sharing” Economy: Issues Facing Platforms, ParTICIPANTS, AND REGULATORS 11 (Nov. 2016) [hereinafter FTC REPORT], https:/www.ftc.gov/system/files/documents/reports/sharing-economy-issues-facing-platforms-participants-regulators-federal-trade-commissionstaff/p151200_ftc_staff_report_on_the_sharing_economy.pdf [perma.cc/H6N8-UX6R].

6 See Peer-to-Peer (P2P) Economy, InvesTOPEDIA, http://www.investopedia.com/terms/p/peertopeer-p2p-economy.asp [perma.cc/WN43QBC6].

6 See FTC REPORT, supra note 5, at 11.

7 See FTC REPORT, supra note 5, at 11.

8 See, e.g., Nicholas A. John, The AgE of SHARING 69 (2016) (noting an "often-heard critique" that sharing is distinct from renting); FTC Report, supra note 5, at 10-11.

9 See John, supra note 8, at 72, 74 (citing sources from 2007).

10 See generally LAWRENCE LESSIG, REMIX (2008). 
cases, adding money into the mix is downright destructive."11 To Lessig in 2008, Netflix, Amazon, and Google are paradigms of the internet-based commercial economy, while Wikipedia and the Linux operating system are paradigms of sharing. 12 Lessig penned his narrower definition before Uber and Airbnb existed.13

Other (and more recent) scholarly analyses accept for-fee services as part of the sharing economy. 14 Distinctions continue to be drawn between a resource use economic model, including renting and fee-free sharing, and the transfer of ownership, including swapping, donating, and selling. 15 For purposes of antitrust analysis, distinctions between renting and selling are immaterial.16 Distinctions between for-fee and fee-free sharing are not likely to change the antitrust analysis, which is broad enough to encompass non-financial transaction terms. 17

The notion of sharing is not new. 18 The term "suggests the possibility of a society in which resources are distributed fairly."19 Long-standing examples of sharing include carpools, a historic mechanism to conserve gasoline and to get around

11 Id. at 146 (footnote omitted).

$12 I d$. at $117-172$.

13 Uber self-dates to 2009 and Airbnb self-dates to August 2008. See Travis Kalanick, Uber's Founding, UBER (Dec. 23, 2010), https://newsroom.uber.com/ubers-founding/ [perma.cc/A23Q-9JSU]; About Us, AIRBNB, https://www.airbnb.com/about/about-us [perma.cc/VYP6-7SVT].

14 See, e.g., Juho Hamari et al., The Sharing Economy: Why People Participate in Collaborative Consumption, 2 J. AsS'N. FOR INFO. SCI. \& TECH. 2047, 2047-50 (2015); RACHel Botsman \& Roo Rogers, What's Mine Is Yours: The Rise of Collaborative Consumption xvi (2010).

15 See Botsman \& Rogers, supra note 14, at 3.

16 It is possible that a rental market will produce different competitive effects than a market for sales. However, the arguments that this Article makes about what section 1 standard to apply do not depend on those differences.

17 Cf. Tomas J. Philipson \& Richard A. Posner, Antitrust in the NotFor-Profit Sector 4 (Nat'l Bureau of Econ. Research, Working Paper No. $12132,2006)("[\mathrm{P}]$ romoting competition is socially valuable regardless of the particular objectives of producers.”).

18 See generally JoHN, supra note 8, at 75-76.

19 Id. at 76. 
HOV restrictions on major commuting routes. For example, the decades-old practice of "slugging" in Washington D.C. permits sharing of unused seats in commuters' cars:

"Slugging" is a term used to describe a unique form of commuting found in the Washington, DC area .... The system of slugging is quite simple. A car needing additional passengers to meet the required 3- person high occupancy vehicle (HOV) minimum pulls up to one of the known slug lines .... The slugs first in line for that particular destination then hop into the car, normally confirming the destination, and off they go. No money is exchanged because of the mutual benefit: the car driver needs riders just as much as the slugs need a ride. 20

The modern sharing economy relies on the internet to accomplish what slug lines have long achieved for commuting into the nation's capital.21 Sharing economy enterprises have emerged in a wide variety of marketplaces, ranging from content/information (YouTube, Wikipedia) and capital (Kickstarter) to transportation, housing, and personal services (Uber, Airbnb, and TaskRabbit). One paper categorized 254 different enterprises meeting its definition of a sharing economy enterprise, 22 while another source noted "'about 600 peerto-peer startups." 23 Most examples include sharing by transferring ownership, whether permanent or temporary, of cars, homes, bicycles, ${ }^{24}$ concert tickets, ${ }^{25}$ and related personal or real property.

20 See About Slugging, SLug-Lines.COM (last updated Aug. 5, 2017

10:41 AM), http://www.slug-lines.com/Slugging/About_slugging.asp [perma.cc/UL8D-DX5K].

21 See Kate Evans, How Technology Has Created a Shared Economy, SovTECH (Apr. 21, 2016), https://sov.tech/technology-created-shared-economy/ [perma.cc/T5BJ-5NY6].

22 Hamari et al., supra note 14, at 2050.

23 FTC REPORT, supra note 5, at 13-14 (quoting FTC Workshop panelist Chiara Farronato).

24 See, e.g., DONKEY REPUBLIC, http://www.donkey.bike [perma.cc/565R-XFLY].

25 See, e.g., STUBHub, https://www.stubhub.com [perma.cc/HUZ6$4 J J G]$. 


\section{Sharing Economy Characteristics}

The term "sharing economy" describes a platform-based mode of exchange between consumers and suppliers. The platform facilitates transactions that search costs and transaction costs would otherwise prevent. In theory, the platform need not be technology-based. The slugging example above dates back more than forty years to the gasoline crisis in the 1970s.26 Farmers markets and college dining hall message boards have long served the matching service that sharing economy firms provide today. 27 However, technology has revolutionized these historic matching systems. That is partly because the modern sharing economy developed concurrently with the refinement of computer-and internet-based communication. 28 It is also because technology-based communication methods are uniquely suited to minimize search and transaction costs through rapid communication and comprehensive data gathering and sorting.

\section{a. Seven Defining Factors}

In its November 2016 Report, Federal Trade Commission ("FTC") staff identified several key features of sharing economy enterprises. 29 First, the FTC recognized that a sharing economy marketplace has three players: consumers, suppliers, and the platform. 30 The platform is what is usually referred to as the "sharing economy firm." The FTC Report also identified the following five factors: that consumers and

26 About Slugging, supra note 20.

27 See FTC REPORT, supra note 5, at 11.

28 According to one source, from 2005-2015, the percentage of U.S. adults using social media increased from $7 \%$ to $65 \%$. Andrew Perrin, Social Media Usage: 2005-2015, PEw RES. CTR. (Oct. 8, 2015), http://www.pewinternet.org/2015/10/08/social-networking-usage-2005-2015

[https://perma.cc/B6N4-8ANH]. This ten-fold increase coincides with the development of Uber and Airbnb, founded in 2009 and 2008, respectively. See supra note 13.

29 FTC REPORT, supra note 5, at 16, 18-20.

30 Id. at 18 . 
sellers are individuals or very small firms; 31 that sellers or service sellers use existing personal assets and thus bear minimal costs of entry; that markets are sufficiently "thick" to enable liquidity; that the platform has appropriate procedures to ensure safety and reliability; and that the platform charges a fee or commission for its matching services. 32

This Article largely accepts the factors identified in the FTC Report for purposes of the analysis in Parts III-V. 33 However, the FTC Report fails to identify one recurring feature of sharing economy enterprises-that of "regulatory disruption." Regulatory disruption is sufficiently frequent and analytically relevant to warrant treatment as a seventh factor. In the following section, this Article describes regulatory disruption and its sibling, regulatory arbitrage. 34

In sum, the seven defining features of a sharing economy marketplace are:

- Three players: consumers, suppliers, and platform;

- Atomistic consumers and suppliers;

- Sellers face minimal entry and exit barriers by avoiding specialized investment;

- Thick markets;

- Platform provides assurance of safety and reliability;

- Platform charges fee or commission; and

31 This factor distinguishes sharing economy enterprises analyzed here from "sharing" firms that are in reality engaged in short-term renting. See, e.g., CAPITAL BIKESHARE, www.capitalbikeshare.com [perma.cc/EAG8HQA3]. Capital Bikeshare's assets are owned by a consortium of municipalities in the Washington D.C. region. See Partners: Municipal Owners, CAPITAL BIKESHARE, www.capitalbikeshare.com/partners [perma.cc/X7Y2PHTS].

32 FTC REPORT, supra note 5, at 19-20.

33 One factor identified in the FTC Report-homogeneity of goods and services-is subject to meaningful challenge. See id. at 19 (citing FTC Workshop panelist Liran Einav). Sharing economy enterprises such as Airbnb, TaskRabbit, and Etsy, among others, involve substantial heterogeneity with regard to products or services as well as prices and idiosyncratic contract terms.

34 See infra Section II.A.2. 
- Regulatory disruption.

\section{b. Nomenclature}

It is necessary to establish nomenclature for the participants in a sharing economy marketplace. The "sharing economy firm" is the platform. Firms do not employ the sellers, affiliating instead on a contract basis-the legal question of employment is not settled in the more centralized sharing economies.35 The "suppliers" are themselves individuals or firms. Finally, the combination of the platform and the suppliers is a "sharing economy enterprise," a phrase this Article uses to escape the economic and antitrust law implications of the word "firm." 36

\section{Regulatory Disruption and Regulatory Arbitrage}

This Article defines a sharing economy marketplace to include the possibility of "regulatory disruption" as a means of avoiding regulatory limits and the ensuing costs that burden established firms. 37 Regulatory disruption and its sibling, regulatory arbitrage, 38 enable sharing economy enterprises to achieve competitive scale through the growth of the combined enterprise (platform plus suppliers) as opposed to entering as a single firm with sufficient capital to bear the costs of regulation. 39

35 See infra note 91 and accompanying text.

36 With regard to the economic question of firm definition, see infra text accompanying notes 89-92 (discussing Coase in the context of the sharing economy). With regard to the single-firm question in antitrust law, see infra Part III.

37 See Nicholas P. Terry, Regulatory Disruption and Arbitrage in Health-Care Data Protection, 17 Yale J. Health Pol'y, L. \& EThics 143, 156-58 (2017).

38 See Victor Fleischer, Regulatory Arbitrage, 89 TEX. L. REV. 227, 229 (2010).

39 See generally Nicole V. Crain \& W. Mark Crain, U.S. Small Bus. Admin., The Impact of Regulatory Costs on Small Firms 54-55 (2010), https://www.sba.gov/sites/default/files/The\%20Impact\%20of\%20Regulatory\%20Costs\%20on\%20Small\%20Firms\%20(Summary).pdf 
In general, regulatory disruption can be expected to occur when the disruptive enterprise adopts a meaningfully different enterprise structure, such that applying an existing regulatory framework is difficult or impossible. 40 The privately operated payment system Bitcoin is an example of one such enterprise. Bitcoin employs an account-settling structure that uses a decentralized block-chain technology entirely distinct from the traditional means for settling accounts in U.S. payment systems. Bitcoin thereby avoids regulatory oversight it might otherwise have borne had it followed a traditional centralized account settlement procedure. 41 Bitcoin developed as a privately ordered payment system and, only after proving its capacity for success at scale, faced the possibility of regulatory oversight. 42

Whether intentionally or otherwise, sharing economy enterprises take advantage of regulatory disruption to achieve competitive scale. 43 For example, Airbnb began with short-

[perma.cc/J72S-8426]. The Crain \& Crain study suggests substantial variation in the economic sector with a per-employee average across the economy, suggesting that small firms bear substantially greater regulatory costs as a result of not having achieved efficient scale.

40 See generally Salil K. Mehra, Antitrust and the Robo-Seller: Competition in the Time of Algorithms, 100 MINN. L. REV. 1323 (2016).

41 See Felix Salmon, When Disruption Meets Regulation, REUTERs (Jan. 30, 2014), http://blogs.reuters.com/felix-salmon/2014/01/30/when-disruption-meets-regulation/ [perma.cc/S9NN-5669]; Primavera de Filippi, Tomorrow's Apps Will Come from Brilliant (And Risky) Bitcoin Code, WIRED (Mar. 8, 2014), https://www.wired.com/2014/03/decentralized-applicationsbuilt-bitcoin-great-except-whos-responsible-outcomes/ [perma.cc/EQ3W6VDQ] ("The actual innovation brought about by Bitcoin is not the currency itself but the platform.").

42 See Primavera de Filippi, We Must Regulate Bitcoin. Problem Is, We Don't Understand It, WIRED (Mar. 1, 2016), https://www.wired.com/2016/03/must-understand-bitcoin-regulate/ [perma.cc/328S-U95H] ("With a 5 billion market cap, Bitcoin is slowly making its way into the digital economy, and a growing number of merchantsincluding Overstock, Newegg, Expedia, Dell and even Microsoft-are now accepting Bitcoin as a possible form of payment for their products. Of course, regulation will be needed eventually, both to address the risks and maximize the benefits of the technology.").

43 See generally Daniel E. Rauch \& David Schleicher, Like Uber, but for Local Government Policy: The Future of Local Regulation of the "Sharing 
term rentals of air mattresses. While probably immune from scrutiny initially due to the de minimis scale, Airbnb also presented a lodging model that confounds the traditional regulatory scheme.44 The typical Airbnb supplier is not a licensed lodging enterprise, does not report income to the taxing authorities, and may or may not make disclosures to its insurance company. At the individual supplier level, Airbnb is effectively a gray market for housing.

Regulatory arbitrage, in contrast, does not rely on a novel enterprise structure flying below the regulatory radar. Victor Fleisher describes regulatory arbitrage instead as "a perfectly legal planning technique used to avoid taxes, accounting rules, securities disclosure, and other regulatory costs." 45 For instance, where employment law imposes costs in the form of health care and social security coverage, firms may seek to avoid treating its labor force as "employees" to avoid those costs. 46 Where antitrust law imposes obligations to self-report transactions over a certain size, firms may seek to conduct transactions on a smaller scale. 47

Sharing economy enterprises achieve characteristics of large integrated firms. These enterprises achieve a substantial "nexus of contracts" that establish terms among the con-

Economy” (Geo. Mason Univ. Law \& Econ. Research Paper Series No. 1501, 2015); Sofia Ranchordas, Does Sharing Mean Caring? Regulating Innovation in the Sharing Economy, 16 MINN. J. L. SCI. \& TECH 413 (2014).

44 See Roberta A. Kaplan, Regulation and the Sharing Economy, N.Y.L.J. (July 18, 2014), https://www.law.com/newyorklawjournal/almID/1202663656633 [perma.cc/3M62-BU9Z] (arguing "new technologies should not be banned outright simply because they cannot be neatly shoehorned into traditional business or regulatory models").

45 See Fleischer, supra note 38, at 229.

46 Taxes and benefits on employee wages are commonly reported to increase the cost of employment versus contracting by a multiple of 1.25-1.4. See generally Internal Revenue Serv., Publication 15-A, EMPloyer's SuPPLEMENTAL TAX GUIDE (2017).

47 See Revised Jurisdictional Thresholds for Section 7A of the Clayton Act, 82 Fed. Reg. 8524 (Jan. 26, 2017) (to be codified at 16 C.F.R. pt. 801803). 
stituent parts of the enterprise, as well as between the constituent parts and third-party consumers. 48 Achieving firmlike stature while retaining the convenience of an enterprise comprised of independent contractors constitutes regulatory arbitrage and possibly regulatory disruption. As the next Subpart demonstrates, sharing economy marketplaces present a challenge to the Coasean distinction between intra-firm transactions and marketplace transactions.

\section{Features of Leading Sharing Economy Enterprises}

Platforms establish "terms of service" that govern relationships between the platform and suppliers. These terms of service also frequently regulate consumers' use of the platform and the contracts between suppliers and consumers. The extent to which platforms exercise control over suppliers and consumers via their terms of service varies. Table 1 below identifies several key functions of such terms of service and whether they are used by particular well-known platforms.

48 See Michael C. Jensen \& William H. Meckling, Theory of the Firm: Managerial Behavior, Agency Costs and Ownership Structure, 3 J. FIN. ECON. 305 (1976) ("It is important to recognize that most organizations are simply legal fictions which serve as a nexus for a set of contracting relationships among individuals."). 
TABLe 1: Platforms' TeRMs of SERVICE FEATURES

\begin{tabular}{|l|c|c|c|c|c|}
\hline & Uber & Lyft & ABB 49 & CS50 & TR51 \\
\hline $\begin{array}{l}\text { Establishes a price for } \\
\text { the service or product } \\
\text { provided }\end{array}$ & $\mathrm{X}^{52}$ & $\mathrm{X}^{53}$ & & $\mathrm{X}^{54}$ & \\
\hline $\begin{array}{l}\text { Controls the method of } \\
\text { payment over the plat- } \\
\text { form }\end{array}$ & $\mathrm{X}$ & $\mathrm{X}$ & $\mathrm{X}$ & & $\mathrm{X}$ \\
\hline $\begin{array}{l}\text { Maintains a functional- } \\
\text { ity for product or ser- } \\
\text { vice reviews }\end{array}$ & $\mathrm{X}$ & $\mathrm{X}$ & $\mathrm{X}$ & $\mathrm{X} 55$ & $\mathrm{X}$ \\
\hline $\begin{array}{l}\text { Sets minimum require- } \\
\text { ments for the sup- } \\
\text { plier's personal or real } \\
\text { property used in the } \\
\text { transaction }\end{array}$ & $\mathrm{X}$ & & & & \\
\hline $\begin{array}{l}\text { Sets requirements } \\
\text { meant to ensure com- } \\
\text { pliance with accessibil- } \\
\text { ity and other civil } \\
\text { rights laws }\end{array}$ & $\mathrm{X}$ & & & & \\
\hline $\begin{array}{l}\text { Disclaims control over } \\
\text { suppliers, including }\end{array}$ & $\mathrm{X}$ & $\mathrm{X}$ & & & \\
\hline
\end{tabular}

49 Airbnb.

50 Couchsurfing.

51 TaskRabbit.

52 Subject to downward negotiation and, as of June 2017, tipping. See In-app Tips on Uber, UBER https://www.uber.com/ride/how-it-works/tips/ [perma.cc/2AL6-6DMQ].

53 Subject to tipping. See How to Tip Your Driver, LYFT, https://help.lyft.com/hc/en-us/articles/213583978-How-to-tip-your-driver [perma.cc/VM7Q-H7SB].

54 Price is required to be zero. See How It Works, Couchsurfing, https://www.couchsurfing.com/\#how-it-works [perma.cc/Y6GY-TKB9].

55 Referred to as "references," these are less robust than the review functions of the for-fee sharing services discussed here. 


\begin{tabular}{|l|l|l|l|l|l|}
\hline $\begin{array}{l}\text { their manner of per- } \\
\text { forming a service or } \\
\text { providing a product }\end{array}$ & & & & & \\
\hline $\begin{array}{l}\text { Collects taxes imposed } \\
\text { by a particular locality }\end{array}$ & & & $\mathrm{X}$ & & \\
\hline $\begin{array}{l}\text { Ensures that realistic } \\
\text { alternative means ex- }\end{array}$ & & & $\mathrm{X}$ & & $\mathrm{X}$ \\
$\begin{array}{l}\text { ist for suppliers to } \\
\text { reach consumers }\end{array}$ & & & & & \\
\hline
\end{tabular}

\section{a. Uber}

Uber first launched in 2010 as a small ride-share company out of San Francisco under the name Ubercab. The company was born in response to the difficulty of hailing a cab in San Francisco and allowed users of the service to flip the script by creating a means for drivers to come directly to those looking for a ride. Ubercab grew in popularity despite its initially higher costs, and eventually expanded into New York in 2011 as Uber. 56 Today, Uber self-reports operations in eighty-two countries, 57 and valuation estimates for Uber range from 60

56 Uber NYC Has Launched, UBER: UBERBLOG (May 4, 2011), https://www.uber.com/blog/new-york-city/uber-nyc-launches-service/ [perma.cc/6ZPE-UHYD].

57 See International Sites, UBER, https://www.uber.com/country-list/ (last visited on Oct. 27, 2017). 
70 billion dollars. 58 According to the most recent comprehensive survey in July 2016, Uber averages 15.8 million monthly active users. 59

Uber's terms of service with consumers establish the platform as a "technology company" and "matching service" between consumers and third party providers of, primarily, ride services. 60 Uber's driver contract (referred to on the Uber website as "terms and conditions" 61 ) similarly limits Uber's role in the transaction to that of "lead generation to independent pro-

58 See, e.g., Uber: The Road to a $\$ 69$ Billion Valuation, WALL STREET SURVIVOR (July 17, 2017), http://blog.wallstreetsurvivor.com/2017/07/17/uber-road-69-billion-valuation/ [perma.cc/QYN7ZKEB]; Maya Kosoff, A Look Inside the Insanely Successful Life of Billionaire Uber CEO Travis Kalanick, BUSINESS INSIDER (July 6, 2015), http://www.businessinsider.com/inside-the-successful-life-of-billionaireuber-ceo-travis-kalanick-2015-7 [perma.cc/3J4E-C7YD]. As a privately held company, such valuation is an estimation. It is frequently questioned. See, e.g., Julie Verhage, An Expert in Valuation Says Uber Is Only Worth $\$ 28$ Billion, Not \$62.5 Billion, BloomBerg (Aug. 27, 2016, 1:32 PM), https://www.bloomberg.com/news/articles/2016-08-17/an-expert-in-valuation-says-uber-may-have-already-peaked [perma.cc/8V3K-5NSW].

59 See Mike Sonders, These Latest Uber Statistics Show How It's Dominating Lyft, MEDIUM (Dec. 7, 2016) https://medium.com/@sm_app_intel/these-latest-uber-statistics-show-how-its-dominating-lyft-53f6b255de5e [perma.cc/7Q43-E9K5].

60 The Services comprise mobile applications and related services (each, an "Application"), which enable users to arrange and schedule transportation, logistics, delivery services, and/or purchase certain goods, including with third party providers of such services and goods under agreement with Uber or certain of Uber's affiliates ("Third Party Providers"). In certain instances, the Services may also include an option to receive transportation, logistics, and/or delivery services for an upfront price, subject to acceptance by the respective Third Party Providers. Unless otherwise agreed by Uber in a separate written agreement, the Services are made available solely for personal, noncommercial use. U.S. Terms of Use, UBER, https://www.uber.com/legal/terms/us/ [perma.cc/8M7U-CKUE].

61 Agreeing to Terms and Conditions, UBER https://help.uber.com/h/44cf1f0e-27ca-4919-9621-f1321a0381c1 (last visited Dec. 2, 2017). 
viders of rideshare or peer-to-peer (collectively, 'P2P') passenger transportation services."62 Drivers "acknowledge and agree that Company is a technology services provider that does not provide transportation services."63 Uber further sets terms governing the relationship between Uber and drivers as well as the contract relationships between drivers and passengers. 64 Of particular note, the Uber driver contract imposes default fares, which drivers may negotiate down at their initiative. 65 The agreement does not describe how such negotiated fares would operate in reality, and there is some evidence that downward fare negotiation is not a reality for ride sharing on the Uber platform. 66 However, the contours of the Uber pricing regime are not static and can be expected to change. In June 2017, Uber added functionality allowing passengers

62 Raiser, L.L.C. Technology Services Agreement (Dec. 11, 2015), https://www.documentcloud.org/documents/2645988-RASIER-TechnologyServices-Agreement-Decmeber-10.html [perma.cc/QLT7-QBR6].

63 Id.

64 See id. at 3-7. These include requirements for use of Uber services; contract termination based on ratings; Uber's role in establishing default fares and collecting those fares; and drivers' status as independent contractors with limited control over driving by Uber. Under the heading "Use of the Uber Services," the driver contract also dictates terms of the transactions between drivers and passengers. These include communications between driver and passenger; driver's obligation to provide equipment and services under the transportation agreement; driver's obligation to transport service animals; ratings made by drivers of passengers and passengers' right to rate drivers; requirements for driver vehicles; "default" fares to be charged, based on location of the ride; adjustments to fares based on local market factors; and adjustments to fares based on driver conduct including an inefficient routing.

65 Id. at 7. In the ordinary course, upward negotiation is not part of the Uber pricing regime. Exceptions include negotiations on long-distance trips and negotiations on multiple stop.

66 An Uber driver's forum, uberpeople.net, contains much discussion about the apparent possibility of negotiating fares, but no indication that any driver had ever actually exercised the apparent contract right to negotiate a lower fare. See generally Jagman, We Can Negotiate the Fare, UBERPEOPLE (Feb. 14, 2017), https://uberpeople.net/threads/we-can-negotiatethe-fare.141426/ [perma.cc/T3DL-WUL8] (containing a Melbourne, Australia, driver discussion board). 
to tip drivers, with the result that the total cost of a ride can now be negotiated upward via a tip. 67

\section{b. Airbnb}

In 2008, Airbnb was founded in San Francisco by three founders who rented out air mattresses for use in their apartment. They created a user-friendly website advertising the space at a rate of $\$ 80$ per person per night, an amount significantly less than local hotels. After three guests rented in a single night, they decided to expand the idea.68 Airbnb now connects people to a wide variety of spaces, including apartments, homes, castles, and villas, in more than 65,000 cities and 191 countries, with over three million listings worldwide. 69 The success of Airbnb may be partially attributed to its personalized customer service, competitive pricing, and creative use of technology.

The Airbnb model is centered on short-term accommodations, where potential guests can browse available listings filtered to meet their needs. For example, upon selecting a destination, a potential guest can filter their search results to specify room type-e.g., a private room, shared room, or entire home-as well as price range. Once the selections have been made, Airbnb displays to the user all accommodation profiles that fit the specifications. These profiles are created by the owner of the accommodation, and typically include photos, reviews by other Airbnb users who have stayed at the accommodation, and a description. 70

Like Uber, Airbnb is a "platform" for matching service providers with consumers of services. 71 The platform charges fees

67 See Can I Tip My Driver With the App?, UBER, https://help.uber.com/h/8459a496-5ed2-4f9d-b15c-d8afd9ccf34f [perma.cc/ZAF8-4PJ4].

68 See Anna Vital, How Airbnb Started, AdIomA (Apr. 10, 2014), http://fundersandfounders.com/how-airbnb-started/] [perma.cc/X4VT7LWB].

69 About Us, AIRBNB, https://www.airbnb.com/about/about-us [perma.cc/G5K3-3ZYD].

70 See AIRBNB, https://www.airbnb.com/ [perma.cc/5U5G-U8P6].

71 According to Airbnb's Terms of Service: 
for its services. 72 Those fees are primarily imposed on the provider of services rather than on the consumer. Airbnb's other roles in the financial aspects of the service transaction include collecting payment from the consumer to make payment to the provider and charging the consumer additional fees for damage incurred. 73 Airbnb does not establish the price of the service provided.

\section{c. Other Examples}

Lyft is another sharing economy firm supporting a ride sharing enterprise by contract with driver/owners. Similar to Uber, Lyft has a smart phone app that allows users to connect with drivers in order to get to a destination of the passenger's choosing. Lyft offers marginally greater flexibility in contract terms than Uber; for instance, Lyft offers the option to tip the driver through the app, a feature historically unavailable for

1.1 The Airbnb Platform is an online marketplace that enables registered users ("Members") and certain third parties who offer services (Members and third parties who offer services are "Hosts" and the services they offer are "Host Services") to publish such Host Services on the Airbnb Platform ("Listings") and to communicate and transact directly with Members that are seeking to book such Host Services (Members using Host Services are "Guests") ... .

1.2 As the provider of the Airbnb Platform, Airbnb does not own, create, sell, resell, provide, control, manage, offer, deliver, or supply any Listings or Host Services. Hosts alone are responsible for their Listings and Host Services. When Members make or accept a booking, they are entering into a contract directly with each other. Airbnb is not and does not become a party to or other participant in any contractual relationship between Members, nor is Airbnb a real estate broker or insurer. Airbnb is not acting as an agent in any capacity for any Member, except as specified in the Payments Terms.

Terms of Service, AIRBNB (last updated June 19, 2017), https://www.airbnb.com/terms [perma.cc/78YD-FKEY].

72 See Payment Terms of Service, AIRBNB (June 19, 2017), https://www.airbnb.com/terms/payments_terms [perma.cc/4G42-5TKH].

73 See id. 
Uber drivers (although this has recently changed). 74 Drivers may serve as suppliers in both the Uber and Lyft enterprises at the same time, and some evidence exists that this is not uncommon. 75

Another sharing economy firm is Couchsurfing. Couchsurfing provides a platform for hosts to spotlight an empty space for travelers. Couchsurfing classifies itself as a hospitality and social networking centered site. The amenities available vary, although most frequently guests receive, as the name implies, a couch. Accommodations listed on Couchsurfing are free. The articulated mission of the platform is to create a space that allows people to "share lives, create connections, offer kindness, stay connected and to leave it better than you found it."76 Couchsurfing became for-profit in 2014.77 But Couchsurfing continues to connect suppliers and consumers for fee-free accommodations and specifically prohibits suppliers from charging for use. 78 Couchsurfing disclaims any role in transactions except for serving as a matching service. 79

\footnotetext{
74 See Uber vs Lyft: A Side-By-Side Comparison, RIDESTER (last updated Nov. 10, 2017), https://www.ridester.com/uber-vs-lyft/ [perma.cc/3ZFC-MPTT]. See supra note 66 for details of Uber's policy change.

75 See id.

76 See Our Values, COUCHSURFING, http://www.couchsurfing.com/about/values/ [perma.cc/LMC7-KXYV].

77 See The Rise and Fall of Couchsurfing, Nithin CocA (Mar. 27, 2013) http://www.nithincoca.com/2013/03/27/the-rise-and-fall-of-couchsurfing/ [perma.cc/B9Q6-3BMZ].

78 According to the Couchsurfing policies:

3. Don't Charge for Your Couch: Our community offers free exchange of hospitality. Asking for money or labor in exchange for your couch, or referring members to paid accommodation services, is not allowed.
}

Couchsurfing Policies, CouchsuRfing, http://www.couchsurfing.com/about/policies/ [perma.cc/65WT-EE5T].

79 The Couchsurfing terms of use state:

Our Services provide a platform for members to learn about one another, arrange stays and travel, engage in activities and communicate with one another. Couchsurfing is not a 
Finally, TaskRabbit provides a matching platform for small-to-medium chores requiring moderate skills, including packing for moves, furniture assembly, home cleaning, general handyman work, personal assistant work, closet organizing, and research, among others. The platform connects suppliers, called "Taskers," with consumers. Taskers list their services for a price on the platform and TaskRabbit facilitates the transaction. Of the enterprises detailed in this Subpart, TaskRabbit exercises the least control over the transactions between suppliers and consumers. It allows for ratings, controls payments, and imposes warranties of timeliness, quality and skills, and expertise on the Taskers. 80

\section{B. Economics of the Sharing Economy}

Transactions occur where the gains, net of search and transaction costs, are positive for both parties (and superior to alternatives). 81 The transactions such as ride sharing and casual lodging services that are taking place in the sharing economy today may not have occurred historically because the search and transaction costs exceeded the potential gains. By

party to, has no involvement or interest in, makes no representations or warranties as to, and has no responsibility or liability with respect to any communications, transactions, interactions, disputes or any relations whatsoever between you and any other member, person or organization. You are solely responsible for your interactions with other members of our Services. We reserve the right, but have no obligation, to monitor interactions between you and other members of our Services.

Remember, the Couchsurfing Services are just a platform that enable you to communicate and interact with other people around the world. We cannot be responsible for the interactions that you have with other Couchsurfing members, so please use good judgment and keep safety in mind when you use our Services.

Terms of Use, Couchsurfing, (last updated July 19, 2017), http://www.couchsurfing.com/about/terms-of-use/ [perma.cc/98XS-5ZXN].

80 See TaskRabbit Terms of Service, TASkRABBIT (last updated June 1, 2017), https://www.taskrabbit.com/terms [perma.cc/42ML-77KF].

81 FTC REPORT, supra note 5, at 18. 
reducing those search and transaction costs, the sharing economy has enabled transactions that could not occur in a preinternet economy.

\section{Efficiencies in the Sharing Economy}

Sharing economy firms succeed by leveraging several key efficiencies, including efficiencies of:

- the online platform;

- low search and transaction costs;

- regulatory disruption and arbitrage; and

- small scale. 82

All of the sharing economy enterprises detailed in Subpart A above operate entirely through online communication. For example, an Uber rider does not contact the firm through a brick-and-mortar store-front. Even online communication is channeled to maximize efficiency. The Uber website landing page lacks a "contact us" link. 83 Once Uber uses its online platform to establish relationships with drivers and riders, it is extremely efficient in connecting drivers with riders. This second efficiency may be Uber's primary reason for quick success. It replaced an outdated labor-intensive system of matching taxi drivers with riders through telephones and dispatch centers. Likewise, Airbnb's matching service, which takes place online and through its smartphone app, reduces search and transaction costs relative to traditional marketing channels.

Other efficiencies are not inherent to the business model, but are instead the result of sharing economy firms' status as disruptors. Because these firms are sufficiently unlike existing providers in their industry, they may end run anachronistic regulatory schemes that date back decades, if not more than a century, to the development of the original industry. Uber demonstrates the reality of hopeless anachronism in the

82 See generally Benjamin G. Edelman \& Damien Geradin, Efficiencies \& Regulatory Shortcuts: How Should We Regulate Companies Like Airbnb and Uber?, 19 STAN. TECH. L. REV. 293 (2016).

83 See UBER, https://www.uber.com/ [perma.cc/C59H-ZMNJ]. 
system of taxicab medallions and rate regulation for taxi fares. Other enterprises, such as Airbnb and TaskRabbit, may fail to collect state or local taxes or satisfy other regulatory requirements such as licensure. Initial small scale allows sharing economy firms to prove new business models to both venture capital firms and regulators, while operating under the radar until larger operating scale is achieved. These efficiencies permit sharing economy enterprises to make meaningful dents in revenues in their respective industries with the benefits flowing to consumers. 84

\section{Both Centralized and Competitive}

Sharing economy enterprises confound regulation that is designed to control centrally coordinated unitary firms. 85 These enterprises can achieve massive scale. By one estimate, the total value of Uber's bookings for its core business line approached $\$ 20$ billion in 2016.86 Uber achieves that value while avoiding both ownership costs for the primary capital investment - the cars - and responsibility as an employer for salary and benefits to its drivers. Instead, Uber acts as facilitator for a substantial market populated by individual competitors. 87

The definitional characteristics of a sharing economy marketplace include its capacity to bring together atomistic suppliers and consumers transacting around relatively homogenous goods and services. The technology that supports the

84 See Georgios Zervas et al., The Rise of the Sharing Economy: Estimating the Impact of Airbnb on the Hotel Industry (Bos. Univ. Sch. of Mgmt., Research Paper No. 2013-16, 2014).

85 See generally Stephen R. Miller, First Principles for Regulating the Sharing Economy, 53 HARV. J. ON LEGIS. 147, 149-51 (2016).

86 See Tyler Durden, Uber's Massive Cash Burn Problem: 2016 Loss Set to Hit a Record \$3 Billion, ZERoHedGe (Dec. 20, 2016), http://www.zerohedge.com/news/2016-12-20/ubers-massive-cash-burn-problem-2016-lossset-hit-record-3-billion [perma.cc/Z5ED-Z2P5] (reporting approximately $\$ 5$ billion quarterly in revenue from rideshare bookings).

87 As a practical matter, selecting a driver on Uber is not a trivial task. Riders must first hail a ride and, if the driver is not to their liking (for example, if the rating score is low), the rider must cancel the ride within the allowed five-minute time period and hail another ride. 
enterprise mitigates historic limitations on information availability. Thus, a sharing economy marketplace may better achieve the idealized perfectly competitive state. Each supplier faces a flat demand curve, representing infinite elasticity. The competitors provide the enterprise with both labor and capital, two of the three factors of production. The competitors also play a decision-making role in their small part of the enterprise over matters such as where to operate, what parts of the day to offer services, and-for instance, in the case of Uber-when to service or replace the vehicles.

Sharing economy enterprises do not escape the need for centralized coordination, however. The platforms exercise varying levels of control over suppliers. At one extreme, some platforms exercise very little control and merely allow consumers and suppliers to find each other. For instance, wellknown platform eBay exercises limited control over suppliers. 88 Of the enterprises considered in Subpart A, TaskRabbit is the least coordinated. At the other extreme, a platform may establish prices and other terms of service. Uber is an example of this higher level of centralized control. The more coordination that exists, the more the sharing economy enterprise presents itself to consumers as a unitary entity. This distinction between competition and monopoly is essential to understanding the antitrust implications of sharing economy marketplaces, discussed further in Parts III-V.

\section{Disrupting the Coasean Firm}

Eighty years ago, Ronald Coase set out to define a firm. Coase distinguished between coordination within a firm and

88 See EBAY, https://www.ebay.com/ [perma.cc/8SXD-N4CD]; see also ETSY, https://www.etsy.com/ [perma.cc/36LG-Y5YY]. Controls over suppliers on eBay, for example, include a short set of "listing conditions," a list of "prohibited and restricted items," and intellectual property rules (ignoring the contract terms between eBay and its suppliers). See eBay User Agreement, eBay, http://pages.ebay.com/help/policies/user-agreement.html\#6 [perma.cc/4MRL-S4Q7]. This two-page set of terms governs a marketplace with approximately $\$ 84$ billion in yearly transactions. See EBAY, 2016 ANNUAL REPORT 4 (2017). 
market transactions between firms. 89 Coordination within a firm was characterized by an entrepreneur who gave direction to employees. The entrepreneur controlled which employees did what and how they did it. If employees did not want to follow these directions, they could quit. In market transactions, on the other hand, the firm purchased goods and services without the power to direct how these goods were produced or services rendered. The firm paid a price for an outcome specified in the contract. Coase reasoned that entrepreneurs would choose between intrafirm coordination and market transactions depending on which offered the best tradeoff of costs and benefits. At the height of the industrial age, large manufacturing firms raised huge amounts of money to build large factories where they directed the work of thousands of laborers to produce steel, cars, and trains.

Sharing economy enterprises realign the ownership and control structure by minimizing the cost of marketplace transactions and reducing the need for aggregating large amounts of capital within a single firm. Transactions previously more efficient when centrally coordinated have become efficient as marketplace transactions. 90 Entrepreneurial control remains within the firm. However, as a matter of definition, sharing economy enterprises outsource labor to independent contractors. 91 Capital ownership is also outsourced, with sharing economy firms contracting with the owners of cars, apartments, bicycles, tools and equipment, or other real or personal property, to rent or sell those assets using the platform. Thus, the enterprise may enjoy many of the efficiencies of an integrated firm while also gaining the efficiencies of marketplace

89 See R. H. Coase, The Nature of the Firm, 4 Economica 386 (1937).

90 See Anders Hansen Henten \& Iwona Maria Windekilde, Transaction Costs and the Sharing Economy, 18 INFO 1, 6-9 (2016).

91 As a legal matter, this is subject to continued debate and litigation. See, e.g., Mumin v. Uber Techs., Inc., 239 F. Supp. 3d 507 (E.D.N.Y. 2017) (assessing a claim for denial of rights through misclassifying drivers as independent contractors and denying motion to dismiss in part). See generally Erin Mulvaney, Regulators \& Lawyers Race to Respond to a Thriving Gig Economy, NAT'L L.J. (Aug. 1, 2017) https://www.law.com/nationallawjournal/almID/1202793484793 [perma.cc/BSM4-L4WP]. 
transactions. 92 The net result is that individuals supply the capital and the labor, while the platform supplies the marketing and varying levels of control.

The Article turns in Part III to an examination of the core antitrust rules that govern firms and transactions in the U.S. economy. Those rules' application in the context of the sharing economy is a matter of existential importance for some or all of these firms.

\section{SHERMAN ACT STRUCTURE}

Federal antitrust law has controlled the legal assessment of competitive behavior for more than 125 years. The Sherman Act is the principal vehicle for that assessment. The basic structure of the Sherman Act divides competitive behavior into classifications and subjects each class to different levels of assessment. Some behavior is automatically lawful. Other behavior is automatically unlawful. The legality of still other behavior depends on its economic effect in the particular circumstance. The Act uses two variables to achieve this differentiation. First, the Act treats conduct differently depending on whether it is the product of an agreement. The Supreme Court has developed complex rules about when an agreement will be deemed to exist and how different agreements will be assessed. Second, the Act treats conduct differently depending on whether the actor(s) have or are close to possessing market power.

Doctrinally, the Act uses a complex set of elements to assess the effects of agreements and market power. Section 1 condemns agreements that unreasonably restrain trade, prohibiting "[e]very contract, combination . . . or conspiracy, in

92 See Dyal-Chand, supra note 5, at 267 ("Sharing markets, and the sharing economy more broadly, seem to violate the claims of Coase and Demsetz . . . . [W] hy do these individuals neither join firms nor go it alone . . . ?"); see generally Yochai Benkler, Coase's Penguin, or, Linux and the Nature of the Firm, 112 YALE L.J. 369 (2002) (discussing the different emphasis on marketplace transactions over hierarchical structure presented by sharing economy enterprises). 
restraint of trade . ..."93 The requirement of a contract, combination or conspiracy is referred to as the agreement or concerted action requirement. For more than one hundred years, the Supreme Court has consistently interpreted the restraint of trade element to prohibit only restraints that are unreasonable.94 Section 2 of the Sherman Act prohibits monopolization and attempted monopolization.95 Monopolization requires power over price and untoward conduct to acquire or maintain that power. 96 Attempted monopolization occurs when an actor is dangerously close to monopoly power, has the specific intent to monopolize, 97 and takes predatory steps toward that end.98 Since sharing economy actors are pioneers in potentially disruptive incursions into existing markets, the possession of or dangerous proximity to monopoly power seems less likely than the potential for anticompetitive contracts.99 Therefore, this Article will focus on analysis of antitrust concerns arising under section 1 of the Sherman Act.

9315 U.S.C. $§ 1$ (2012).

94 See Standard Oil Co. of N.J. v. United States, 221 U.S. 1, 61-62 (1911).

9515 U.S.C $\S 2$ (2012). Section 2 also prohibits conspiracies to monopolize. See id. This prohibition has little practical importance since such a conspiracy would already be illegal under $\S 1$.

96 United States v. Grinnell Corp., 384 U.S. 563, 570-71 (1966) ("The offense of monopoly under $\S 2$ of the Sherman Act has two elements: (1) the possession of monopoly power in the relevant market and (2) the willful acquisition or maintenance of that power as distinguished from growth or development as a consequence of a superior product, business acumen, or historic accident.").

97 See Spectrum Sports, Inc. v. McQuillan, 506 U.S. 447, 459 (1993).

98 See Lorain Journal Co. v. United States, 342 U.S. 143, 149 (1951).

99 Monopolization has been alleged against one sharing economy enterprise, Uber, in federal lawsuits in the Eastern District of Pennsylvania and in the Northern District of California. See Phila. Taxi Ass'n, Inc. v. Uber Techs., Inc., 218 F. Supp. 3d 389 (E.D.Pa. 2016) (attempted monopolization claim dismissed for lack of standing); DeSoto Cab Co. v. Uber Techs., Inc., No. 16-CV-06385 (N.D. Cal. filed Nov. 2, 2016). The claim in the Northern District of California is unlikely to succeed due to difficulties alleging and proving monopoly power. 


\section{A. The Agreement Requirement}

Agreements and conspiracies are familiar concepts in areas of the law as diverse as contracts and criminal law. However, the competitive policies underlying the Sherman Act have given rise to a specialized body of law. First, the Act has been interpreted to insulate conduct within a single firm from scrutiny under section 1 . Second, some conduct between firms, which is in some sense collaborative, is sometimes deemed unilateral.

The single entity fiction protects intrafirm conduct. The thousands of people involved in the business decisions of a large publicly held corporation as officers, directors, and employees are each individual actors. If they got together to sell cocaine or pursue a terrorist attack, they would be guilty of criminal conspiracy. The existence of the corporation would not insulate them from guilt. However, under the Sherman Act, those actors are deemed to be a single entity and incapable of conspiring with each other while they pursue the firm's interests. Two modern Supreme Court cases explore the boundaries of this doctrine. In Copperweld Corp. v. Independence Tube Corp., 100 a parent corporation and its wholly-owned subsidiary were alleged to have conspired in violation of section 1. Previous opinions of the Court had stated that such a conspiracy was possible.101 After considering the policy behind the concerted action requirement, the Court held that a conspiracy between a parent corporation and its wholly-owned subsidiary was not possible under section 1.102

In American Needle, Inc. v. National Football League,103 the Court returned to the single entity fiction. The thirty-two team members of the National Football League were alleged to have agreed among themselves when the NFL licensing

100 See Copperweld Corp. v. Indep. Tube Corp., 467 U.S. 752 (1984).

101 See e.g., United States v. Yellow Cab Co., 332 U.S. 218, 229 (1947); Kiefer-Stewart Co. v. Joseph E. Seagram \& Sons, Inc., 340 U.S. 211, 212 13 (1951).

102 See Copperweld Corp., 467 U.S. at 768-72.

103 See American Needle, Inc. v. Nat'l Football League, 560 U.S. 183 (2010). 
arm granted an exclusive license to Reebok to use team trademarks on caps.104 Of course, the contract between the league and Reebok was itself an agreement subject to scrutiny under section 1. However, a horizontal agreement among the teams would be subject to separate, more searching, scrutiny. After examining the holding and policy discussion in Copperweld,105 the Court held that the league members were not joined together in a single entity. They were therefore capable of conspiring with one another for purposes of section 1.106 The Court reasoned that the league members did not have a sufficient unity of economic interest to constitute a single entity for Sherman Act purposes. 107

Determining whether more than one entity exists is only the first step in an agreement analysis. The next question is whether those firms have entered into an agreement. Sometimes this is easy. Two or more firms may enter into an express contract. Similarly, an organization may adopt rules to govern the conduct of its members. 108 Other times the agreement question is factually or legally more difficult. Factually, firms may deny that they ever talked to each other or otherwise communicated and were unconcerned with each other's conduct. Legally, courts may be called upon to determine whether interdependent conduct constitutes an agreement. Both of these issues were raised in Bell Atlantic Corp. $v$. Twombly.109 The plaintiffs there alleged that the defendant telecommunications companies had agreed to divide the country into territories and refrain from competing with one another. The defendants argued that the complaint failed to adequately allege the agreement. At one level this is a straightforward factual dispute. Did the defendants communicate with one another and divide up the market? The Court

104 Id. at 187.

$105 I d$. at $194-95$.

$106 \mathrm{Id}$. at 201.

107 Id. at 197-202.

108 See, e.g., Nat'l Collegiate Athletic Ass'n v. Bd. of Regents of Univ. of Okla., 468 U.S. 85, 104 (1984); Nat'l Soc'y of Prof'l Eng'rs v. United States, 435 U.S. 679,683 (1978).

109 See Bell Atl. Corp. v. Twombly, 550 U.S. 544 (2007). 
held that the complaint did not adequately allege that they had.110 At another level, the dispute requires answering a complex legal question.

Conduct by two or more firms can be divided into three categories. Firstly, they may enter into a communicated agreement. Secondly, they may act completely independently; they may refrain from communicating and be unconcerned about each other's behavior. Finally, firms may act in an interdependent manner. Interdependence arises when firms observe each other and react to each other's behavior. The relevance of interdependent behavior under section 1 has been discussed for more than a half century. ${ }^{111}$ In Twombly, the Court stated that interdependent behavior does not constitute an agreement. 112

In summary, an agreement under section 1 requires two or more firms to enter into a communicated agreement. These questions of law and proof regarding the agreement question are critical to understanding the treatment of sharing economy enterprises under the Sherman Act. These enterprises present questions of both (1) single entity status and (2) independence, interdependence, or coordination of conduct. Of course, not every agreement between two or more firms is illegal under section 1. Agreements are illegal only if they unreasonably restrain trade.

\section{B. The Unreasonableness Requirement}

Although the text of section 1 literally prohibits every agreement in restraint of trade, the Act has long been interpreted to prohibit only unreasonable restraints of trade. ${ }^{113}$ The unreasonableness of an agreement may be demonstrated in either of two ways. Some agreements are unreasonable per

$110 I d$. at 566.

111 See Donald F. Turner, The Definition of Agreement Under the Sherman Act: Conscious Parallelism and Refusals to Deal, 75 HARV. L. REV. 655, 671-72 (1962).

112 See Twombly, 550 U.S. at 553-54.

113 See Chi. Bd. of Trade v. United States, 246 U.S. 231, 238-39 (1918). 
se.114 Other agreements are subject to the rule of reason that assesses the competitive effect of the agreement in the particular situation. Per se illegal agreements include price fixing 115 and market allocation by competitors. 116 It was the per se rule against market allocation by competitors that was at issue in Twombly.117 The per se rules against price fixing and market allocation by competitors demonstrate that the antitrust laws are generally more concerned about agreements among competitors. These agreements are referred to as horizontal agreements.

\section{Defining the Categorical Prohibition of Per Se Rules}

Whenever the law defines a rule based on a category of conduct, the definition of that category becomes crucial. Per se rules against horizontal price fixing and market allocation require that the agreement be among competitors. However, the law further divides horizontal agreements and subjects only some of them to the per se rule. The Supreme Court has sometimes struggled with determining the exact parameters of the horizontal per se rules. In Broadcast Music, Inc. v. Columbia

114 See Leegin Creative Leather Prods., Inc. v. PSKS, Inc., 551 U.S. 877, 886 (2007).

115 United States v. Socony-Vacuum Oil Co., 310 U.S. 150, 223 (1940) ("Under the Sherman Act a combination formed for the purpose and with the effect of raising, depressing, fixing, pegging, or stabilizing the price of a commodity in interstate or foreign commerce is illegal per se.”).

116 United States v. Topco Assocs., Inc., 405 U.S. 596, 608 (1972) ("One of the classic examples of a per se violation of $\S 1$ is an agreement between competitors at the same level of the market structure to allocate territories in order to minimize competition."). In addition to price fixing and market allocation by competitors, the Supreme Court has sometimes stated that boycotts and tying are per se illegal. See, e.g., Klor's, Inc. v. Broadway-Hale Stores, Inc., 359 U.S. 207 (1959) (assessing boycotts); N. Pac. Ry. Co. v. United States, 356 U.S. 1 (1958) (assessing tying).

117 See Twombly, 550 U.S. at 550-51. Because Twombly was decided on the question of whether an agreement existed, the Court did not address the question of the reasonableness of the conduct. 
Broadcast System, Inc.,118 CBS claimed that the defendant copyright pools had violated the per se rule against horizontal price fixing. The defendants were pools of copyright owners who combined to offer a blanket license to all of the copyrights in the pool. The blanket license was priced by the pool. This arrangement involved a horizontal agreement by competitive licensors of copyrights and did determine the price of the blanket license. Thus, in the plaintiff's view, the agreement was per se illegal as horizontal price fixing.

The Court held that since the agreement was price fixing only in the "literal sense," it was not subject to the per se rule.119 The Court noted that the blanket license was not something that any of the copyright holders could sell themselves. 120 Competition among copyright holders for licenses to their individual copyrights remained unaffected by the agreement to form the copyright pools and offer the blanket license. 121 Thus, the parameters of the per se rule against horizontal price fixing were refined in $B M I$. In addition to horizontality in the agreement and an effect on price, an agreement is per se illegal as price fixing only if it affects the price at which the parties will sell something that they could have sold individually. 122 This process of refinement is potentially in play whenever the law uses a categorical rule. The parameters of the rule must be defined to advance the policy behind the rule. If a categorical rule cannot be defined in such a way that it advances the policy behind the rule, the categorical approach should be rejected.

118 See Broad. Music, Inc. v. Columbia Broad. Sys., Inc., 441 U.S. 1 (1979).

119 See id. at 8.

$120 I d$. at 23. ("ASCAP does set the price for its blanket license, but that license is quite different from anything any individual owner could issue.").

121 See id. at 23-24.

122 See also Arizona v. Maricopa Cty. Med. Soc'y, 457 U.S. 332, 356 (1982) (focusing on whether the agreement affected the price of goods or services that the parties to the agreement could have sold individually also controlled the outcome). 


\section{Reducing the Number of Per Se Rules}

During the last forty years, the Supreme Court has reduced the number of per se rules and overturned several that condemned agreements that were not horizontal. An agreement between a buyer and a seller is referred to as a vertical agreement. The simplest form of a vertical agreement is a contract of sale which merely sets the price in the sale transaction. Obviously, an ordinary contract of sale does not violate the Sherman Act. However, sometimes a seller seeks to control the resale of the product by the buyer. The seller may want to control how much the buyer charges on resale. Such an agreement is referred to as resale price maintenance. The seller may want to control to whom the buyer resells the product. Such a restriction might be geographic or based on some other classification of customers. These agreements are referred to as vertical non-price restrictions on distribution. Starting in 1911, minimum resale price maintenance was condemned as a violation of section 1.123 Maximum resale price maintenance was condemned as per se illegal in 1968.124 In 1967, the Supreme Court applied a per se rule to vertical nonprice restrictions. 125 Between 1977 and 2007, all of these per se rules were overturned and replaced by assessment under the rule of reason. 126 This trend toward reducing the number of per se rules and increasing the application of the rule of reason has important consequences.

123 See Dr. Miles Med. Co. v. John D. Park \& Sons Co., 220 U.S. 373 (1911), overruled by Leegin Creative Leather Prods., Inc. v. PSKS, Inc., 551 U.S. 877 (2007).

124 See Albrecht v. Herald Co., 390 U.S. 145, 153 (1968), overruled by State Oil Co. v. Khan, 522 U.S. 3 (1997).

125 See United States v. Arnold, Schwinn \& Co., 388 U.S. 365, 381-82 (1967), overruled by Cont'l T.V., Inc. v. GTE Sylvania Inc., 433 U.S. 36 (1977).

126 See Cont'l T.V., 433 U.S. at 36 (holding that vertical non-price restrictions are subject to the rule of reason); State Oil Co., 522 U.S. at 3 (holding that maximum resale price maintenance is subject to the rule of reason); Leegin Creative Leather Prods., 551 U.S. at 877 (holding that minimum resale price maintenance is subject to the rule of reason). 
Since vertical agreements to set resale prices and allocate markets are subject to the rule of reason, it becomes crucial to distinguish them from horizontal agreements allocating markets or setting prices. For example, if Toyota entered into agreements with each of its dealers requiring the dealers to sell a Camry for a specified price from a specified location, those agreements would be subject to the rule of reason. However, if two or more Toyota dealers agreed with each other to sell Camrys at an agreed upon price or to refrain from locating their dealerships near each other, those agreements would be per se illegal.

Therefore, the agreement requirement discussed in the previous part is not only important as a threshold element for any scrutiny under section 1 . It is also important for determining what type of agreement is present. As in American Needle, the existence of one agreement is sometimes easy to determine. There it was the contract between the NFL licensing entity and Reebok. That agreement would be vertical in nature since it was between a licensor and a licensee of intellectual property. As a vertical agreement, it would be subject to the rule of reason. The issue in the case was whether, in addition to this vertical agreement, a horizontal agreement was also present. The Court determined that the teams were separate entities capable of conspiring together. Of course, the teams were in a horizontal relationship as potentially competing licensors of their own trademarks. A horizontal agreement that eliminated competition between these potential competitors and gave rise to the agreement with Reebok would be subject to closer scrutiny under section 1 than the vertical agreement would be standing alone.

\section{The Rule of Reason: Fast and Slow}

Agreements that are not per se illegal under section 1 are subject to assessment under the rule of reason. The rule of reason involves a potentially complex analysis of the competitive effects of the agreement. Instead of taking a categorical approach, the rule of reason attempts to assess the legality of an agreement by determining the potential anticompetitive 
and procompetitive effects of the alleged agreement. This matter of degree approach avoids the necessity of defining a category of illegal conduct. However, the matter of degree approach does require an assessment of both potential anticompetitive and procompetitive effects and netting those effects against each other. This process can involve complex allocations of burdens at different stages of the assessment.

The threshold question in a rule of reason case is whether the plaintiff has presented enough evidence of anticompetitive potential to shift the burden to the defendants to present a possible procompetitive justification. In three cases, the Supreme Court concluded quite quickly that the plaintiffs had met this burden. In National Society of Professional Engineers $v$. United States, 127 the defendant association had adopted a rule that prohibited its members from engaging in competitive bidding. The Court concluded that because the agreement affected prices, the plaintiff had demonstrated the anticompetitive potential of the agreement.128 In NCAA $v$. University of Oklahoma, 129 the defendant association had limited the number of football games that could be broadcast on television. It also sold groups of games to broadcast networks for package prices. The Court concluded that the agreement had sufficient potential for an adverse effect on competition to require the defendant to offer a justification. 130 Finally, in FTC. $v$. Indiana Federation of Dentists, 131 the defendant association had adopted a rule that forbid its members from providing insurance companies with patients' $\mathrm{x}$-rays when submitting a claim. The Court held that such an agreement was potentially anticompetitive without an elaborate analysis. 132 These three cases are examples of a "quick look" approach to the threshold

127 Nat'l Soc'y of Prof'l Eng'rs v. United States, 435 U.S. 679 (1978).

128 Id. at 692 .

129 Nat'l Collegiate Athletic Ass'n v. Bd. of Regents of Univ. of Okla., 468 U.S. 85 (1984).

130 Id. at 113.

131 FTC v. Indiana Fed'n of Dentists, 476 U.S. 447 (1986).

132 Id. at 459 . 
question in a rule of reason case. However, not all rule of reason cases are suitable for this quick look approach to that threshold question.

In California Dental Association v. FTC,133 Justice Souter and Justice Breyer debated when a quick look approach to the threshold question under the rule of reason was appropriate. In a five-four split, Justice Souter's view that a quick look approach was inappropriate in that case prevailed. The defendant association had adopted a set of rules that appeared to be aimed at false advertising by dentists. However, the rules had been applied to prohibit advertising prices as low, across the board discounts and quality claims. 134 The question before the Court was whether that finding was enough to shift the burden to the defendant to offer a procompetitive justification. Justice Souter, writing for the majority, held that the agency had not met its burden of establishing a sufficient likelihood of anticompetitive effects to shift the burden to the defendant. 135 Justice Breyer disagreed. He argued that the anticompetitive potential of the advertising restrictions required the defendant to present evidence of procompetitive effects. 136

Determining whether the plaintiff has demonstrated sufficient likelihood of anticompetitive effects is not the only difficult question in applying the rule of reason. If the plaintiff has made the required demonstration, the burden shifts to the defendant to offer a justification for the agreement. This justification must focus on the procompetitive effects of the agreement. This requirement proved difficult for defendants in some of the cases discussed above. In Professional Engineers, the defendant association tried to justify its ban on competitive bidding by arguing that competitive bidding would lead to poor quality engineering. 137 The Court rejected this defense as asserting that competition would lead to negative consequences rather than arguing that the agreement enhanced

133 Cal. Dental Ass'n v. FTC, 526 U.S. 756 (1999).

134 See id. at 783.

135 Id. at 778 .

136 Id. at 784 (Breyer, J. concurring in part and dissenting in part).

137 Nat'l Soc'y of Prof'l Eng'rs v. United States, 435 U.S. 679, 693 (1978). 
competition, and explained that "the Rule of Reason does not support a defense based on the assumption that competition itself is unreasonable." 138 Similarly, in Indiana Federation of Dentists, the defendants argued that giving the insurance companies access to the diagnostic x-rays would lead to negative results. 139 Citing Professional Engineers, the Court rejected this argument as an attack on the concept of competition rather than an argument that the agreement furthered competition. ${ }^{140}$ Finally in $N C A A$, the defendants argued that the agreement restricting the number of games on television was necessary in order to preserve ticket sales for live attendance at football games. 141 The Court rejected this argument since it was based on the assumption that live ticket sales could not compete with televised games in the absence of the restraint. 142 Citing Professional Engineers, the Court rejected this argument. 143

In summary, the basic structure of section 1 of the Sherman Act is based on three categorical rules backed up by one matter of degree rule. The first categorical rule is the single entity fiction. The single entity fiction requires that two or more entities that meet the requirements of the rule exist. The rule is categorical since it attempts to define a set of criteria for what is a single entity. It is a fiction since it ignores the actual people within each defined entity. The second categorical rule is the requirement that the entities engage in a communicated agreement. This rule establishes a parameter that excludes interdependent behavior from the definition of an agreement. The third categorical rule is the per se rule, which renders conduct illegal without regard to its effects. Per se rules define sets of agreements that are automatically illegal. Each per se rule has its own set of parameters. The back-up matter of degree rule is the rule of reason. If conduct is not

$138 I d$. at 696.

139 FTC v. Indiana Fed'n of Dentists, 476 U.S. 447, 462-63 (1986).

140 Id. at 463.

141 Nat'l Collegiate Athletic Ass'n v. Bd. of Regents of Univ. of Okla., 468 U.S. 85, 115 (1984).

142 Id. at 117.

143 Id. 
legalized by the single entity fiction or the exclusion of interdependent behavior from the definition of an agreement and is not condemned by a per se rule, its competitive effects are analyzed by the shifting burdens of the rule of reason.

The net effect of the combined impacts of these rules is to strongly encourage some types of cooperation while strongly discouraging other types of cooperation. Cooperation within a firm is strongly encouraged, since it is automatically legal under section 1. Similarly, cooperation by interdependence is strongly encouraged since it too is automatically legal under section 1. However, achieving cooperation through agreements that are subject to a per se rule is strongly discouraged since a court will not hear any procompetitive arguments in support of such agreements. If an agreement is subject to the rule of reason, it is discouraged to the extent that a plaintiff will be able to quickly shift the burden to the defendant to offer a procompetitive justification and to the extent that the defense arguments are based on asserting that competition is itself harmful.

This discussion of the structure of section 1 lays the foundation for analyzing its application to sharing economy enterprises. Part IV undertakes that analysis.

\section{APPLYING THE SHERMAN ACT TO THE SHARING ECONOMY}

The preceding part described the structure of section 1 of the Sherman Act. This section will analyze the issues presented in applying section 1 to sharing economy arrangements. The analysis proceeds by asking four questions. First, are the participants in a sharing economy arrangement separate firms capable of conspiring for purposes of section 1? Second, what is the nature of the agreements among these firms? Third, are any of these agreements subject to a rule of per se illegality? Fourth, how are any other agreements to be assessed under the rule of reason?

These issues are not merely academic. A purported class action made up of consumers of Uber's services has sued Uber CEO Travis Kalanick, alleging a horizontal conspiracy between Kalanick and other Uber drivers to use Uber's pricing 
algorithm to fix the price of rides.144 "Plaintiff claimed, in essence, that Mr. Kalanick, while disclaiming that he was running a transportation company, had conspired with Uber drivers to use Uber's pricing algorithm to set the prices charged to Uber riders, thereby restricting price competition among drivers to the detriment of Uber riders, such as plaintiff Meyer."145

Judge Rakoff noted the many features of the Uber enterprise that led to the high level of coordination among the drivers, effected through the Uber platform, including the de facto lack of individual price negotiation (despite the permissibility of downward deviation from algorithmically established prices). ${ }^{146}$ Rejecting Uber's argument that the Uber driver agreements were individual vertical agreements with Uber and not a horizontal agreement with one another, the District Court noted the historic judicial recognition of hub-and-spoke conspiracies in antitrust. 147 The District Court denied the motion to dismiss the claim of a price fixing conspiracy. 148 This Article considers below how the law of section 1, described in detail in Part III, above, should be applied to sharing economy enterprises like Uber.

\section{A. Agreement Analysis}

The threshold question in a section 1 analysis is whether the participants in any coordinated behavior are separate entities capable of entering into an agreement under section 1 .

144 See Meyer v. Kalanick, 174 F. Supp. 3d 817, 819-20 (S.D.N.Y. 2016).

145 Id. at 820

146 Id. at $820-21$.

147 Id. at 824 (citing Interstate Circuit, Inc. v. United States, 306 U.S. 208 (1939) and United States v. Apple, Inc., 791 F.3d 290 (2d Cir. 2015)). A hub-and-spoke conspiracy is an agreement reached between two or more parties who communicate through a common third party (the hub) although they may not actually communicate with each other. See In re Disposable Contact Lens Antitrust, 215 F. Supp. 3d 1272, 1292 (M.D. Fla. 2016).

148 The application of an arbitration clause in the Uber passenger agreement with passengers has recently been analyzed by the U.S. Second Circuit Court of Appeals. That court concluded that the arbitration clause was valid and enforceable, remanding to the District Court on the question of waiver. See Meyer v. Uber Techs., Inc., 868 F.3d 66 (2d Cir. 2017). 
When the Supreme Court addressed this question in Copperweld, it determined that a parent corporation and its wholly owned subsidiary were a single entity for purposes of section 1.149 When the Court addressed the question of whether the teams belonging to the National Football League comprised a single entity in American Needle, it reached the opposite conclusion. 150 In both cases, the Court focused on whether the actors were pursuing a unified economic interest. "The officers of a single firm are not separate economic actors pursuing separate economic interests, so agreements among them do not suddenly bring together economic power that was previously pursuing divergent goals."151 "Although NFL teams have common interests such as promoting the NFL brand, they are still separate, profit-maximizing entities, and their interests in licensing team trademarks are not necessarily aligned." 152

Actors joining in a sharing economy arrangement are each pursuing their own separate economic interests and are therefore not protected by the single entity fiction. Uber and each of its drivers are separate economic actors; some of these actors might make money while others suffer losses. Uber takes a piece of each driver's revenue but does not share each cost, and the drivers share neither revenues nor costs. The same is true for Airbnb and each of its property owners.

\section{Types of Sharing Economy Agreements}

Concluding that participants in the sharing economy arrangements are separate entities capable of conspiring under section 1 is only the first step in the agreement analysis. The next step is determining whether the parties have entered into any agreements. Of course, some agreements in sharing

149 See supra text accompanying notes 98-100.

150 See supra text accompanying notes 101-105.

151 Copperweld Corp. v. Indep. Tube Corp., 467 U.S. 752, 769, 771 (1984) (“[T]he coordinated activity of a parent and its wholly owned subsidiary must be viewed as that of a single enterprise for purposes of $\S 1$ of the Sherman Act. A parent and its wholly owned subsidiary have a complete unity of interest. Their objectives are common, not disparate ....").

152 American Needle, Inc. v. Nat'l Football League, 560 U.S. 183, 198 (2010). 
economy arrangements are easy to spot. For example, Uber drivers enter into express agreements with Uber that contain complex terms related to insurance, driving record, nature of the vehicle, and payment methods. Similarly, riders agree with Uber by accepting terms and conditions when signing up for the Uber app. ${ }^{153}$ These agreements include terms related to the nature of the vehicle, locations served, and payment methods. Beyond these express agreements, other agreements are also possible.

One might consider the driver and the rider to be in an agreement. Under this conception, Uber is providing a matching service. It tells both drivers and riders that it will help them find each other and that it will coordinate the terms of their deal. This conception of the arrangement characterizes Uber as selling a service both to drivers and to riders. It is compensated for this service by the difference between what the rider pays and what the driver receives. In pure contract law terms, identifying an agreement between the driver and the rider seems straightforward. The rider sends a trip request. The driver accepts the request. The terms of the deal are set by the Uber terms and conditions of service. These agreements are very benign from a Sherman Act perspective. Uber is selling a matching service to both drivers and riders, and the driver is selling a transportation service to the rider. These sale agreements are vertical agreements between consumers and suppliers. Vertical contracts of sale are not anticompetitive. Rather, they are the basic mechanics of a market economy.

\section{Horizontal Agreements Among Suppliers?}

An important question is whether the Uber drivers should be viewed as in agreements with one another. Among sharing economy enterprises, Uber imposes the most substantial control over suppliers. When accepting the terms and conditions as an Uber driver, each driver is agreeing with Uber. Are they also agreeing with one another? From a purely contractual

153 U.S. Terms of Use, UBER (Mar. 23, 2017), https://www.uber.com/legal/terms/us/ (last visited Dec. 2, 2017). 
perspective, the answer seems to be no. The drivers never directly communicate with one another, and none of the drivers make an offer that is accepted by another driver. However, this contract law determination does not control the Sherman Act question.

The Sherman Act prohibits contracts, combinations and conspiracies in restraint of trade. 154 The concept of a conspiracy is not limited to contractually enforceable promises. Further, the word "combination" is more commodious than the confines of an enforceable contract. The agreement analysis of Uber's coordination of driver activity is similar to, but differs from, other well-known agreement contexts. This Subpart considers (1) vertical restrictions on distribution, (2) membership organizations, (3) horizontal joint ventures, and (4) joint sales agencies.

\section{a. Vertical Restrictions on Distribution}

One well known context for Sherman Act agreements involves restricted distribution imposed by sellers on reselling buyers. ${ }^{155}$ Sherman Act analysis of restricted distribution by the Supreme Court goes back more than a century.156 As discussed in the previous part, in restricted distribution a supplier tells a buyer where, to whom, and/or at what price the buyer may resell. While at various points in history these agreements were illegal per se, current law subjects them to the rule of reason. 157 Vertical agreements about territories, customers, or resale price need to be distinguished from horizontal agreements about these same topics. Agreements among competitors, horizontal agreements, allocating territories or customers, or fixing prices are per se illegal.158 Thus,

15415 U.S.C. $\S 1$ (2012).

155 See supra text accompanying notes 122-125.

156 See Dr. Miles Med. Co. v. John D. Park \& Sons Co., 220 U.S. 373 (1911), overruled by Leegin Creative Leather Prods., Inc. v. PSKS, Inc., 551 U.S. 877 (2007).

157 See supra text accompanying notes 122-125.

158 See supra text accompanying notes 114-115. 
the distinction between vertical agreements restricting distribution and horizontal agreements determines whether the agreements are per se illegal or subject to the rule of reason. A manufacturer may agree with each of its retailers about where, to whom, and for how much the retailers may resell the manufacturer's products, and these vertical agreements may be lawful under the rule of reason. 159 However, if those same retailers agree with each other about any of those topics, their agreement is per se illegal. The fact that the manufacturer has entered into a set of vertical agreements with its retailers by itself does not mean that the retailers are in an agreement with each other. Such a horizontal agreement would need to be established by other facts. 160

Well-established law permits a plaintiff to prove a horizontal agreement effected by a set of seemingly unilateral vertical agreements. In Interstate Circuit $v$. United States, the Supreme Court recognized that a horizontal conspiracy might arise through a scheme orchestrated at one level of the chain of distribution. This horizontal conspiracy by vertical agreement could arise if the offer was accepted by more than one actor at a different level of chain of distribution who recognized that its competitors had also been offered and were accepting the agreement.161 Plaintiffs made this argument in opposition to Uber's efforts to dismiss the consumer suit alleging a horizontal conspiracy. 162 The Second Circuit recently affirmed a finding of liability for an Interstate Circuit-like, vertically orchestrated, horizontal agreement. In Apple e-Books, the Department of Justice succeeded in convincing the District Court that Apple, an e-book retailer, had orchestrated a price-fixing agreement among e-book publishers. 163 The Second Circuit affirmed, noting the historic acceptance of hub-

159 See Leegin Creative Leather Prods., 551 U.S. at 877; Cont'l T.V., Inc. v. GTE Sylvania Inc., 433 U.S. 36 (1977).

160 See Bus. Elecs. Corp. v. Sharp Elecs. Corp., 485 U.S. 717, 730 n.4 (1988).

161 Interstate Circuit, Inc. v. United States, 306 U.S. 208, 227 (1929).

162 See Meyer v. Kalanick, 174 F. Supp. 3d 817, 823 (S.D.N.Y. 2016).

163 See United States v. Apple Inc., 952 F. Supp. 2d 638, 690-91 (S.D.N.Y. 2013). 
and-spoke conspiracies that do not necessitate express agreement among horizontal competitors. 164

Sharing economy arrangements do not literally fit the vertical restricted distribution mold. Uber does not sell a good to the drivers that the drivers then resell to the rider. Therefore, the agreement that the Uber's drivers all charge the same price for the service they sell to the rider does not involve a set of vertical resale price maintenance agreements. Rather, Uber merely provides a matching service that helps drivers and riders find one another. The drivers then provide a service to their riders at a price established by the Uber algorithm.

\section{b. Membership Organizations}

Another familiar context for the analysis of agreements under section 1 involves membership organizations. In a line of cases that date back to 1918, the Supreme Court has concluded that the members of such an organization are all party to an agreement, 165 and declined to characterize such arrangements as a set of individual agreements between the organization and each member. For example, the Court concluded that members of the Indiana Federation of Dentists agreed with each other to withhold x-rays from insurance companies.166 The Court also concluded that thousands of members of the National Society of Professional Engineers

164 See United States v. Apple Inc., 791 F.3d 290, 314 (2d Cir. 2015).

165 See, e.g., Chi. Bd. of Trade v. United States, 246 U.S. 231 (1918).

166 The relevant factual findings are that the members of the Federation conspired among themselves to withhold $\mathrm{x}$ rays requested by dental insurers for use in evaluating claims for benefits, and that this conspiracy had the effect of suppressing competition among dentists with respect to cooperation with the requests of the insurance companies. As to the first of these findings there can be no serious dispute: abundant evidence in the record reveals that one of the primary reasons-if not the primary reason-for the Federation's existence was the promulgation and enforcement of the so-called 'work rule' against submission of $\mathrm{x}$ rays in conjunction with insurance claim forms.

FTC v. Ind. Fed'n of Dentists, 476 U.S. 447, 455 (1986). 
agreed together to refrain from competitive bidding. 167 Similarly, the Court deemed the college members of the NCAA to be in an agreement to restrict the number of televised football games and establish prices for those broadcast rights. 168 The Court also viewed an agreement among the physician members of the Maricopa County Medical Association to charge no more than the prices fixed by the Association as horizontal and per se illegal.169 Members of each of these organizations agreed to abide by the rules established by the organization. Each of these agreements existed among the members and were horizontal in nature.

However, the sharing economy arrangements do not literally involve membership organizations. Uber is not a club with members. It is a seller of a service to both drivers and riders, and part of this service is establishing the price that the drivers will charge the riders. Unlike membership organizations, Uber drivers are not literally joining a group or agreeing to abide by the rules that the group imposes on its members.

\section{c. Joint Ventures}

A third familiar context for the analysis of agreements under section 1 involves joint ventures. In a production joint venture, two or more firms agree to cooperate in producing a product or service. These firms may or may not have been

167 Nat'l Soc'y of Prof'l Eng'rs v. United States, 435 U.S. 679, 692 (1978) ("In this case we are presented with an agreement among competitors to refuse to discuss prices with potential customers until after negotiations have resulted in the initial selection of an engineer.").

168 Nat'l Collegiate Athletic Ass'n v. Bd. of Regents of Univ. of Okla., 468 U.S. 85, 99 (1984) ("By participating in an association which prevents member institutions from competing against each other on the basis of price or kind of television rights that can be offered to broadcasters, the NCAA member institutions have created a horizontal restraint-an agreement among competitors on the way in which they will compete with one another.").

169 Arizona v. Maricopa Cty. Med. Soc'y, 457 U.S. 332, 356-57 (1982) ("The agreement under attack is an agreement among hundreds of competing doctors concerning the price at which each will offer his own services to a substantial number of consumers."). 
competitors prior to the formation of the venture. The Supreme Court analyzed a production joint venture in Texaco, Inc. $v$ Dahger, 170 in which two oil companies, Texaco and Shell, agreed to combine their gasoline refining assets. The joint venture produced and owned the gasoline, which it sold under the Texaco and Shell trademarks.171 The plaintiff alleged that the agreement constituted per se illegal price fixing by competitors. The Court held that the per se rule did not apply since the gasoline sold pursuant to the agreement was jointly owned by the firms in the venture. 172 Essentially, Texaco and Shell shared the profits made from the sale of the gasoline that they jointly owned through the venture. The hallmark of such a joint venture is that the agreeing parties jointly produce a good or service. The sale of this jointly owned good or service produces profits (or losses) that are shared by the venturers.

In a sharing economy arrangement, the agreeing suppliers do not jointly produce a good or service that they jointly sell. Rather, the agreeing suppliers jointly market goods or services separately produced by the suppliers-for example, each individual Uber driver provides rides to separate riders. There is no joint production of the underlying service. Some individual Uber drivers may make profits while other drivers may suffer losses.

\section{d. Joint Sales Agencies}

Perhaps most analogous to a sharing economy arrangement is a joint sales agency. In Appalachian Coals v. United States, 173 a group of coal companies formed a corporation to act as their sales agent. The agent had authority to set the prices at which the coal was sold.174 The Court treated this agreement as existing among the coal companies. 175 Although

170 Texaco, Inc. v. Dagher, 547 U.S. 1 (2006).

171 See id. at 4.

172 Id at 8.

173 Appalachian Coals, Inc. v. United States, 288 U.S. 344 (1984).

174 Id. at 358 .

175 Id. at 364 . 
this arrangement is broadly analogous to sharing economy arrangements, there are distinctions. For example, Uber drivers did not form and do not own Uber. Instead, Uber is a separate company seeking its own profits. However, it is unclear whether this distinction should make a difference. Each driver knows that there are other drivers simultaneously agreeing with Uber. Uber tells each of the drivers that all of the drivers will be charging the price determined by the Uber algorithm. Each driver agrees to this arrangement.

In summary, the Uber arrangement seems more analogous to the organization cases and the joint sales agent cases than the joint venture cases or the vertical restriction on distribution cases. Unlike a joint production venture, Uber and its drivers do not jointly own the production produced by their coordinated behavior. Unlike a vertical restriction on distribution, Uber does not produce something that is then resold by its drivers. Like the organization cases, drivers agree to common terms governing each of their conduct. And like the joint sales cases, drivers produce the service that is then marketed and priced by Uber. This tends to indicate that the Uber drivers are in an agreement with each other. A horizontal agreement among suppliers in a sharing economy enterprise raises the possibility of a determination of per se illegality or quick look treatment under the rule of reason. The following Subparts consider these possibilities."

\section{B. Is the Uber Arrangement Per Se Illegal?}

Concluding that Uber drivers are in an agreement with each other is the first step in analyzing the potential application of the per se rule against horizontal price fixing. The next step is determining whether that agreement results in the drivers all charging the same price. As discussed in Part II, the current Uber terms and conditions make the price determined by the Uber algorithm a "default" price. However, Uber has not implemented any mechanism through which the drivers can conveniently inform riders of their willingness to accept less (or demand more) than the "default" price. When a driver accepts a trip request and arrives to pick up a rider, 
there is no incentive for the driver to accept less than the "default" price. Therefore, the agreement between Uber and each driver leads to price uniformity. If, as discussed in the prior Subpart, the drivers are in an agreement with each other, that agreement leads to the same price uniformity.

If Uber drivers are deemed to be in an agreement with each other to price according to the Uber algorithm, this has potentially profound consequences. 176 Agreements among competitors about prices are ordinarily per se illegal.177 Such a conclusion would make Uber's entire business model a violation of section 1, giving rise to treble damage remedies and, theoretically, criminal exposure. 178

\section{The Scope of the Per Se Rule}

Although courts have most frequently applied the per se rule against price fixing by competitors to classic cartels, they have also applied the rule to less patently anticompetitive conduct. For example, the rule was articulated in United States v. Socony-Vacuum Oil Co., where there was no express agreement over a set price.179 In Socony-Vacuum, the Supreme Court faced an agreement by major oil companies to coordinate purchases from independent refiners to remove what the defendants believed was excess production from the market. 180 The Court upheld the criminal conviction of the defendants, stating that "[u]nder the Sherman Act a combination formed for the purpose and with the effect of raising, depressing, fixing, pegging, or stabilizing the price of a commodity in

176 See Nowag, supra note 3.

177 See United States v. Socony-Vacuum Oil Co., 310 U.S. 150, 223 (1940).

178 Section 1 violations all carry the potential for criminal penalties. As a matter of practice and the application of prosecutorial discretion, however, criminal penalties are almost exclusively sought in the context of what are termed "hard core cartels"-agreements to fix price or output or to divide markets that are formed in secret. See generally U.S. DEP'T OF JUSTICE, ANTITRUST DIVISION MANUAL IV-12 (5th ed. 2017).

179 Socony-Vacuum Oil Co., 310 U.S. at 150.

180 Id. at 167. 
interstate or foreign commerce is illegal per se."181 In Arizona v. Maricopa County Medical Society, the defendant organization of doctors promulgated maximum fees schedules that the defendants asserted lowered the price of medical care.182 The Supreme Court applied the per se rule to this agreement despite its alleged price reducing effects. 183 In Catalano, Inc. $v$. Target Sales, Inc., the defendant beer wholesalers allegedly agreed that they would demand payment at or prior to delivery to their retailer customers. ${ }^{184}$ Prior to this alleged agreement, the defendants sometimes accepted payment several weeks following delivery. 185 The Court of Appeals held that this agreement was not subject to the per se rule against price fixing. The Supreme Court reversed in a per curium holding, "It is virtually self-evident that extending interest-free credit for a period of time is equivalent to giving a discount equal to the value of the use of the purchase price for that period of time. Thus, credit terms must be characterized as an inseparable part of the price." 186 These cases demonstrate little tolerance for horizontal agreements affecting prices.

The Supreme Court has declined to apply the per se rule in some situations in which competitors have agreed to fixed a price. In NCAA $v$. University of Oklahoma, 187 the defendant association of universities sold broadcast rights for football games to television networks and fixed the prices for those broadcast rights. 188 The Court did not apply the per se rule despite the horizontal price fixing agreement, emphasizing that the context required some form of horizontal cooperation. "[W] hat is critical is that this case involves an industry in which horizontal restraints on competition are essential if the

181 Id. at 223 .

182 Arizona v. Maricopa Cty. Med. Soc'y, 457 U.S. 332, 342 (1982).

183 Id. at 348.

184 Catalano, Inc. v. Target Sales, Inc., 446 U.S. 643, 644 (1980).

185 Id.

186 Id. at 648.

187 Nat'l Collegiate Athletic Ass'n v. Bd. of Regents of Univ. of Okla., 468 U.S. 85 (1984).

188 Id. at $99-100$. 
product is to be available at all."189 Uber might argue that the same is true in its situation. To the extent that its drivers are deemed to be in an agreement with each other, Uber might argue that at least some form of horizontal cooperation is necessary for the ride service to be offered to consumers through its app. 190

\section{Broadcast Music, Inc. v. CBS}

In Broadcast Music, Inc. v. CBS, competing copyright holders agreed together to pool their copyrights and offer licensees a blanket license to all of the copyrights in the pool.191 The defendants were required by a prior consent decree to accept only nonexclusive licenses to the copyrighted music.192 This preserved competition among the copyright holders in licensing individual copyrights. Of course, when the defendants offered the blanket license created by their agreement to customers, they needed to set a price for the blanket license. Thus, the defendants were a group of competitors who got together and agreed to fix a price. The Court held that this agreement was not per se illegal, and reasoned that the defendants were not fixing the price of anything that they could individually create and sell.193 Instead, the defendants were creating something new and selling it in competition with their other individual offerings. "But the blanket license cannot be wholly equated with a simple horizontal arrangement among competitors. ASCAP does set the price for its blanket license, but that license is quite different from anything any individual owner could issue. The individual composers and

$189 I d$. at 101.

190 There are reports of off-platform coordination among Uber drivers designed to manipulate the surge pricing algorithm. By jointly logging out of the Uber app. during peak use times, drivers can cause the surge pricing algorithm to kick in and increase the amount paid for rides. See generally Le Chen et al., Peeking Beneath the Hood of Uber, FTC (Sept. 2015), https:/www.ftc.gov/system/files/documents/public_comments/2015/09/ 00011-97592.pdf [perma.cc/JKX8-JRX8].

191 Broad. Music, Inc. v. Columbia Broad. Sys. Inc., 441 U.S. 1, 5 (1979).

192 Id. at 11.

193 Id. at 23. 
authors have neither agreed not to sell individually in any other market nor use the blanket license to mask price fixing in such other markets."194

The implications of $B M I$ for Uber and similar enterprises are complex and important. Whether the suppliers in a sharing economy enterprise like Uber engage in horizontal price fixing subject to the per se rule or produce a previously unknown product or service, invoking the rule of reason, may be determinative of the viability of these enterprises. The Uber arrangement has introduced a new set of suppliers to the market. Uber's agreements with both drivers and riders allow drivers to offer rides in a way not previously practicable. It adds capacity to the marketplace, exerting downward pressures on prices in markets previously served only by regulated taxis. However, it is a leap to conclude that the Uber enterprise creates something that the individual drivers could not produce on their own. Any individual ride is provided by one driver for one price. Unlike $B M I$, the rider is not purchasing unlimited rides from a group of drivers for a single fee. Uber drivers are not cooperating to create a bundle of rides to be purchased by a rider. A single ride is something that a single driver could theoretically offer to a rider. On the other hand, that single driver could not realistically find the rider who wants that particular ride without a matching company like Uber, and Uber could not offer that service without agreements with multiple drivers.

\section{The Ancillarity Doctrine}

$B M I$ can be characterized as an application of a body of law called the ancillarity doctrine. The doctrine was set forth by William Howard Taft when he was a judge on the Court of Appeals for the Sixth Circuit in U.S. v. Addyston Pipe \& Steel Co. 195 At the time, courts were struggling with how to incorporate a reasonableness requirement into section 1 analysis without allowing cartelists to argue that the price they had

194 Id. at 23-24.

195 United States v. Addyston Pipe \& Steel Co., 85 F. 271 (6th Cir. 1898). 
fixed was reasonable. 196 Then Judge Taft offered the ancillarity doctrine as an analytical tool to solve this problem. He held that restraints of trade should be lawful if they reasonably furthered the purposes of a lawful contract.197 He explained, for example, that a covenant not to compete would be lawful if it was reasonably ancillary to the sale of a business.198 Of course, the price fixed by a cartel is not ancillary to any other lawful contract, and would thus be illegal. $B M I$ is an easy case under the ancillarity doctrine. The copyright holders agreed together to create the blanket license. The challenged price agreement merely put a price on this new product. The blanket license could not be sold without a price. Therefore, the agreement to create the price was reasonably ancillary to the lawful purpose of introducing the blanket license to the market.

If the ancillarity doctrine is applied to the sharing economy arrangements, some outcomes are easy and some are more analytically challenging. Airbnb imposes restrictions on its property owners regarding health and safety, disclosure of various characteristics of the property, a customer review regime, and antidiscrimination rules. All such agreements can be defended as reasonably ancillary to the lawful purpose of matching renters with property owners. Airbnb does not impose a pricing agreement on its property owners. Similarly, Uber drivers agree to a series of contract terms that seem reasonably ancillary to the lawful purpose of matching drivers to riders. These include terms related to insurance, driving record, nature of the vehicle, and method of payment. However, the tougher question under the ancillarity doctrine is whether the agreement to charge the price determined by the Uber pricing algorithm is reasonably ancillary to the matching service provided by Uber.

The reasonableness of the connection between a price agreement and lawful contractual purpose varies by context. In $B M I$, the contractual purpose of selling the blanket license

196 See e.g., United States v. Trans-Missouri Freight Ass'n, 166 U.S. 290 (1897); United States v. Joint Traffic Ass'n, 171 U.S. 505 (1898).

197 Addyston Pipe \& Steel Co., 85 F. at 282.

198 Id. at 281. 
could not be accomplished without the price agreement. If Airbnb property owners agreed about the price of their rental properties, such an agreement would not be reasonably ancillary to the matching service offered by Airbnb. Renters using Airbnb often book their reservations days, weeks, or months in advance. They have plenty of time to consider various properties prior to booking. This comparison involves location, property type, size, amenities, and, of course, price. Property owners compete regarding all of these aspects of the transaction. The context of Uber transactions is different. First, the rides offered by Uber drivers are more uniform than properties offered by Airbnb owners. Most importantly, all of the competing Uber drivers are offering a ride to and from the rider's selected locations. Second, the Uber rider is booking their ride much closer in time to the provision of the driving service. Third, the Uber booking process is very quick.

Do the temporal aspects of the Uber transaction make the pricing agreement reasonably ancillary to the matching service? Reducing the number of variables contributes to the speed of negotiating a contract. When a consumer purchases a carton of milk in the checkout line of a grocery store, very few contract terms need to be individually negotiated. The transaction takes place very quickly. When a commercial tenant rents an office building, many terms need to be individually negotiated. The transaction takes more time. Eliminating price competition among Uber drivers contributes to the speed of the matching transaction. However, that does not necessarily make the agreement to charge the same price reasonably ancillary. Price competition is at the core of a market economy. That centrality is the reason for the per se rule against price fixing. An argument that price competition needs to be eliminated faces a high hurdle.

\section{Fast Sharing Economy Transactions Without Price Fixing}

Could the matching service provided by Uber be accomplished while maintaining price competition among Uber drivers? Theoretically, a rider could solicit offers from Uber drivers after identifying the starting and ending points of the 
desired ride. Uber drivers could engage in an online auction to identify which driver is willing to offer the ride for the lowest price. This auction could be limited to a short period of time. If this process is practical, then the agreement to charge the price specified by the Uber algorithm would not be reasonably ancillary to the matching service provided by Uber. On its face, the practicality of such an auction seems doubtful. The prospect of Uber drivers generating competing bids, possibly while driving, seems awkward at best. However, it may be possible to simplify the process without agreeing to abide by the Uber algorithm price. The bidding process would be much simpler if the price determined by the Uber algorithm was just the starting point for the negotiation.199 Drivers could then bid by offering percentage discounts off (or increases above) the Uber algorithm price. Drivers could decide in advance that they would always bid a certain percentage below (or above) the Uber algorithm price. Presumably this discount (or surcharge) could be specified in advance by each driver and automated into the bidding process. Under these conditions, the bidding process might be rapid and relatively painless. If that is so, the current agreement to charge the price determined by the Uber algorithm would not be reasonably ancillary to the provision of the matching service, and the per se rule against horizontal price fixing would apply.

\section{If the Uber Arrangement Is Not Per Se Illegal, Who Bears What Burdens Under the Rule of Reason?}

It is possible that Uber may succeed in avoiding the application of the per se rule against horizontal price fixing. If so, the rule of reason would apply. As discussed in Part III, the application of the rule of reason requires the shifting of burdens between the plaintiff and the defendant on three questions. 200 The plaintiff bears the initial burden of demonstrating the likelihood of anticompetitive effects. If the plaintiff establishes that likelihood, the burden shifts to the defendant

199 The authors are grateful to Professor Benjamin Cover for this suggestion.

200 See supra text accompanying notes 127-143. 
to present a procompetitive justification. If the defendant does so, the burden shifts back to the plaintiff to show that the anticompetitive effects outweigh the procompetitive effects.

The agreement among Uber drivers to charge the price determined by the Uber pricing algorithm creates a sufficient likelihood of anticompetitive effects that the plaintiffs could quickly meet their burden on the threshold question. A horizontal agreement regarding price is as likely to have anticompetitive effects as the agreements in the three cases where the Supreme Court quickly determined that the plaintiffs met their initial burden. In Professional Engineers, the Court quickly concluded that the association's rule prohibiting competitive bidding was sufficiently likely to be anticompetitive that the defendants needed to offer a procompetitive justification. ${ }^{201}$ In Indiana Federation of Dentists, the Court quickly concluded that the agreement to refuse to supply x-rays to the insurance companies was similarly likely to be anticompetitive and similarly required a justification from the defendants. 202 Finally, in NCAA, the Court held that the association's agreement to limit the number of televised games and determine a price for packages of games was sufficiently likely to have anticompetitive effects that the plaintiff had carried their burden on the initial question under the rule of reason. ${ }^{203}$ An agreement among Uber drivers regarding the price to charge riders is similarly likely to have anticompetitive effects. Such a conclusion would shift to Uber the burden of presenting a procompetitive justification.

Faced with this burden, Uber would offer the procompetitive effects of the entry into the market for rides that its app creates. However, the difficulty for Uber would be linking these procompetitive effects to the agreement on price. The massive entry of drivers into the ride market is of course significantly procompetitive. However, Uber would bear the burden of establishing a causal nexus between the procompetitive

201 Nat'l Soc'y of Prof'l Eng'rs v. United States, 435 U.S. 679, 694-95 (1978).

202 FTC v. Ind. Fed'n of Dentists, 476 U.S. 447, 459 (1986).

203 Nat'l Collegiate Athletic Ass'n v. Bd. of Regents of Univ. of Okla., 468 U.S. 85, 113 (1984). 
effects of entry and the agreement on price. In $N C A A$, the Court addressed a similar issue. The association argued that creating a balance of athletic talent among teams served a procompetitive interest of enhancing the quality of the product it offered.204 The Court agreed.205 However, the Court concluded that there was no logical connection between this procompetitive effect and the restriction on television broadcasts that the association adopted.206 Therefore, the presence of a procompetitive effect justifies a restraint on competition only if there is a logical nexus between the procompetitive effect and the restraint. The procompetitive effects of the market entry resulting from the Uber app would justify the price agreement only if there was a logical nexus between the entry and the price agreement. Uber bears the burden of establishing this nexus. The possibility of this nexus might be enough to justify avoiding the application of the per se rule against price fixing. However, like in $N C A A$, the possibility might exist, but when the defendant is called upon to establish the presence of the nexus rather than its mere possibility, the defendant might fail.

If Uber succeeded in establishing the logical nexus between the price agreement and the market entry facilitated by its app, the burden would shift back to the plaintiff to show that the anticompetitive effects outweigh the procompetitive effects. If the procompetitive entry logically depended on the price agreement, the plaintiff would not be able to successfully bear this burden. In such a case, the market entry would not occur without the price agreement. The price agreement thus limits only competition that would not occur at all in the absence of the agreement.

$204 I d$. at 117.

$205 I d$.

206 Id. at $117-19$. 


\section{LESSONS FOR THE STRUCTURE OF A SHARING ECONOMY ENTERPRISE}

Part IV shows that when applying black-letter antitrust law to different sharing economy enterprises, the terms imposed by different platforms influence the antitrust treatment. The primary analysis in Part IV discusses the Uber platform and its terms of service, including the de facto no negotiation price term. It concludes, first, that those terms and conditions lead to a horizontal agreement among the drivers regarding price. Second, the possibility that price identity is required for the Uber system to work makes per se treatment inappropriate. Third, under a quick look version of the rule of reason, Uber would be required to establish such a logical nexus between the price identity agreement and the efficiency of its system.

In this Part, this Article provides a novel structure for analyzing the antitrust standard to apply to a sharing economy enterprise. 207 Subpart A establishes a comprehensive framework for distinguishing among sharing economy enterprises based on two variables: the degree of sharing of risk among the actors and the extent and subject matter of the coordination among them. Subpart B draws generalizable lessons for sharing economy enterprise structure.

\section{A. Diagramming Section 1 Conduct}

The approach stated here is more willing than traditional antitrust law to treat both sets of variables as matters of degree rather than categorical rules. Regarding the degree of risk-sharing, current antitrust law treats the "single entity" question as a binary distinction. $208 \mathrm{~A}$ single entity is exempt from scrutiny under section 1 , while multiple entities are subject to the application of section 1 when they agree with each

207 The analysis here is likely generalizable to non-sharing-economy enterprises. We postpone that generalization to another article.

208 See Mark Anderson, The Enigma of the Single Entity, 16 U. PA. J. Bus. L. 497, 507-08 (2014) (discussing the rule of per se legality for intrafirm agreements). 
other. This existing categorical approach leaves sharing economy enterprises subject to the full range of section 1 assessment since actors within such enterprises do not share profits and losses to such an extent that they meet the categorical approach of existing antitrust law.

Current antitrust law also imposes categorical rules regarding the extent and subject matter of the coordination among actors.209 Some types of coordination among some types of actors are illegal per se. This Article argues that such categorical distinctions are inappropriate when applied to sharing economy enterprises. Rather, the extent of coordination should be viewed as a matter of degree and compared to the extent of risk-sharing. Even price fixing among competitors may be acceptable if the degree of risk-sharing is sufficiently extensive.

Figure 1 graphically portrays the interaction of two variables: coordinated behavior and risk-sharing. 210 Coordination of behavior by potentially competing economic actors threatens the efficiency that competition promotes. Section 1 subjects coordinated actions to scrutiny because of this threat. On the other hand, risk-sharing by economic actors has the potential to promote efficiency. At the extreme of risk-sharing, the single entity fiction protects some forms of coordinated actions from section 1 scrutiny. Although the single entity fiction is nominally addressed to the conduct element, it is based on the likelihood of procompetitive effects. The sharing of profits and losses that is at the core of the single entity fiction incentivizes the maximization of revenues and minimization of costs (i.e., economically efficient behavior). Risk-sharing short of complete sharing of profits and losses may also promote economic efficiency. Sharing economy enterprises involve varying amounts of risk-sharing and varying levels of coordination.

209 See Broad. Music, Inc. v. Columbia Broad. Sys., Inc., 441 U.S. 1 (1979).

210 The graph is more than a sliding scale of pricing restrictions. The primary contribution of this Part is illustrating and providing intuition as to the interplay between the pricing control variable and the risk-sharing variable. 
The point of this Article is that antitrust law should allow increased levels of coordination when a sharing economy enterprise involves increased levels of risk-sharing. This Article explains the graph in detail before plotting the locations of leading sharing economy enterprises based on an assessment of their contract terms with suppliers in Subpart B.

\section{FIGURE 1: RISK-SHARING VS. COORDINATION}

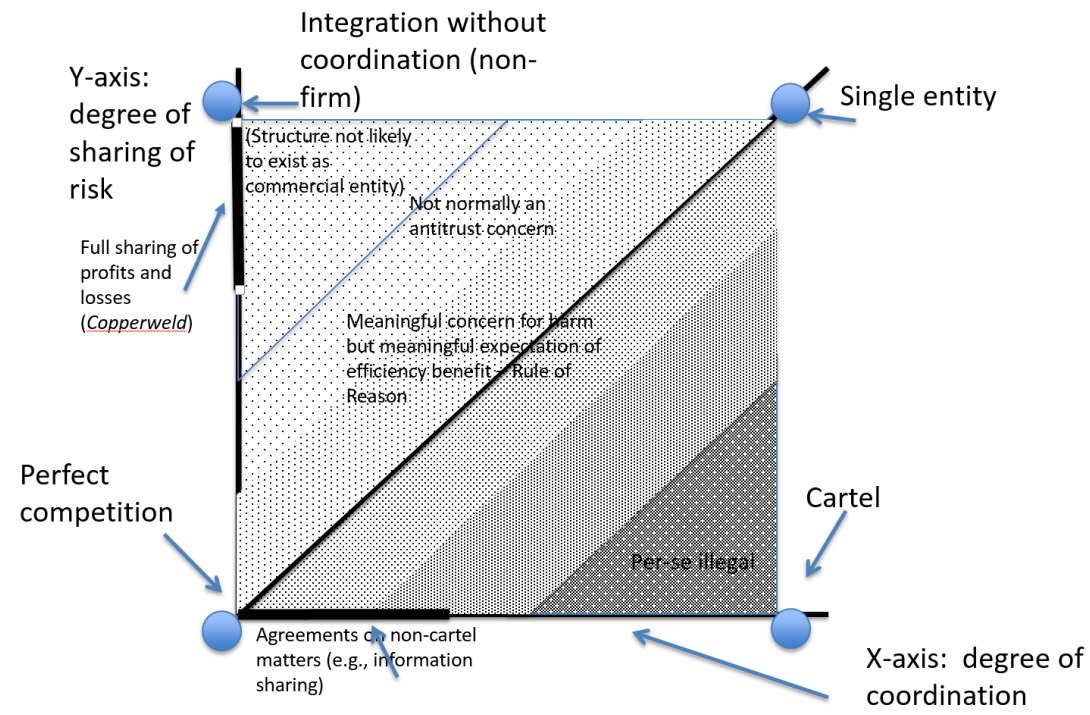

\section{X-Axis: Degree of Coordination}

The X-axis represents the degree of coordination among the constituent parts of the particular enterprise. At the extreme end, where $\mathrm{X}$ approaches infinity, coordination among the constituent parts is complete and relates to the most competitively sensitive matters. At the junction with the Y-axis, where $\mathrm{X}$ approaches 0 , coordination is reduced and the subjects of coordination become less competitively sensitive.

With regard to activity taking place on the X-axis, where $\mathrm{Y}=0$, there is no sharing of risk between the constituent parts of the enterprise-the parts are in competition and gain no efficiency from their coordination. Thus, at the far left end where $(\mathrm{X}, \mathrm{Y})=0$, there is perfect competition among individual 
firms each pursuing their own best interest without regard to other firms. In economics textbooks, this is frequently reflected in a market for commodities, such as wheat, with atomistic producers and consumers, ease of entry and exit, and perfect information. 211

Moving to the right on the $\mathrm{X}$-axis $(\mathrm{Y}=0, \mathrm{X}>0)$, the degree of coordination increases, requiring an analysis of the degree of harm from the observed conduct. A small X represents harmless coordination. Real world examples might include competing firms' sharing information that is not competitively sensitive or sharing past information that has been rendered anonymous. 212 Such exchanges of information are unlikely to lead to any harmful marketplace effects. In practical terms, a plaintiff bringing a rule of reason case alleging conduct with small X will be unable to bear its burden of proving likelihood of harm, and a defendant will be able to rest without its own demonstration of procompetitive effect. 213

Beyond the very minimal coordination, as $\mathrm{Y}=0$ and $\mathrm{X}$ increases, enterprises are subject to higher scrutiny, which leads to the quick look rule of reason. ${ }^{214}$ When enterprises lack any risk-sharing among their constituent parts but involve coordination on competitively sensitive matters, plaintiffs will increasingly be able to demonstrate harm and eventually rely on the presumption of harm provided by the quick look rule. 215 Such a presumption arises, for example, when distinct firms providing dental care, not sharing risk, reach an agreement not to provide x-rays to insurers. 216

211 See generally Robert Pindyck \& DANiel Rubinfeld, MicroeconomICS (7th ed. 2014).

212 See, e.g., Maple Flooring Mfrs. Ass'n v. United States, 268 U.S. 563, 586 (1925).

213 See supra Part III (discussing the burden shifting under the rule of reason)

214 Since Cal. Dental, this has been understood to be a sliding scale rather than a binary rule-of-reason versus per-se distinction. See Cal. Dental Ass'n v. FTC, 526 U.S. 756, 781 (1999) ("an enquiry meet for the case").

215 See id. at 787-84 (Breyer, J., dissenting) (labeling "obvious" and not "possible to deny" the anticompetitive tendencies of private agreements not to advertise discounts).

216 See FTC v. Ind. Fed'n of Dentists, 476 U.S. 447, 454-55 (1986). 
Finally, when the coordination touches on matters like price, output, and product or geographic markets, which are forbidden subjects of competitor coordination, it becomes subject to rules of per se illegality. Examples include an agreement among service providers to divide geographic markets 217 and an agreement among electronic book publishers to raise the retail price of e-books.218 Cartel conduct, giving rise to criminal enforcement, exists at the extreme right end of the $\mathrm{X}$-axis. 219 The $\mathrm{X}$-axis thus reflects a progression from no coordination, passing through innocent coordination on harmless matters and risky coordination, and eventually reaching highly anticompetitive coordination among wholly unintegrated entities.

\section{Y-Axis: Sharing of Risk}

The Y-axis represents the degree of risk-sharing among the constituent parts of the particular sharing economy enterprise. At the end where Y approaches infinity, the constituent parts are engaged in full sharing of profits and losses and are acting as a single firm. 220 At the junction with the $\mathrm{X}$-axis, where $\mathrm{Y}$ approaches 0 , sharing of risk is reduced to the point at which the constituent parts are engaged in vigorous competition. Increased risk-sharing is an indicator of increasing likelihood of efficiency. When an enterprise is comprised of independent competitors, incentives to maximize profits and minimize losses across the entire enterprise are lacking. Increased risk-sharing within the enterprise incentivizes increased efficiency; at the extreme end of risk-sharing, full sharing of profits and losses, formerly independent competitors, are fully invested their mutual success. Thus, as Y approaches infinity otherwise independent competitors may be

217 See United States v. Topco Assocs., Inc., 405 U.S. 596, 607-08 (1972).

218 See United States v. Apple, Inc., 791 F.3d 290, 339 (2d Cir. 2015).

219 See, e.g., United States v. Andreas, 39 F. Supp. 2d 1048, 1054 (N.D. Ill. 1998) (upholding a jury verdict on price fixing conviction for the Archer Daniels Midland executive).

220 Anderson, supra note 208 (defining single firm after American Needle, Inc. v. Nat'l Football League, 560 U.S. 183 (2010)). 
treated as a single firm that is immune from antitrust scrutiny. 221 For example, fast food franchises and their common franchisor have been treated as a single entity, although each pursued its own economic interests. 222

With regard to activity taking place along the $\mathrm{Y}$-axis when $\mathrm{X}=0$, there is no coordination between the constituent parts of the enterprise. Thus, at the point $\mathrm{Y}=0$, the market is in a state of perfect competition. As Y increases, there is an increase in risk-sharing among the constituent parts. At the extreme end, where $\mathrm{Y}$ approaches infinity, risk-sharing is complete and the constituent parts are sharing profits and losses. At that point, increased coordination is also extremely likely. If actors agree to share risk, they are also likely to coordinate their activities. This coordination could take the form of shared and equal control, like in a partnership. It could also take the form of centralized management accompanied by fiduciary duties, as in a corporation. 223

221 See Freeman v. San Diego Ass'n of Realtors, 322 F.3d 1133, 1147 (9th Cir. 2003) ("The single-entity rule is relevant in a variety of contexts. It applies to a company and its officers, employees and wholly owned subsidiaries."). Cf. American Needle, Inc., 560 U.S. at 191 ("concerted action under $\S 1$ does not turn simply on whether the parties involved are legally distinct entities"); PHILliP E. AREEDA \& HERBERT HovenKAMP, ANTITRUST LAW ๆ 1466-1467 (3d ed. 2010) (explaining that parent and non-whollyowned subsidiaries can be accorded single firm treatment). The District Court in In re Term Commodities Cotton Futures Litig., 2014 U.S. Dist. LEXIS 145955, at *5 (S.D.N.Y. Sept. 30, 2014), recognized that Copperweld's bright-line rule did not accommodate all circumstances of risk-sharing among firms that might provide a basis for making a single entity determination. "[W]hen lower courts are faced with the question of whether an affiliated, but not wholly owned, corporation can conspire with its parent in violation of $\S 1$, they must draw from the analysis in Copperweld without the benefit of a bright line rule." Id. at *13.

222 Williams v. I.B. Fischer Nevada, 794 F. Supp. 1026, 1031 (D. Nev. 1992), aff'd, 999 F.2d 445, 447 (9th Cir. 1993) (per curiam).

223 Holding $\mathrm{X}$ at 0 , the likelihood that an enterprise will exist decreases as $\mathrm{Y}$ increases. It is unlikely that firms will exist at a point where $\mathrm{X}=0$ and $\mathrm{Y}$ is significantly greater than 0 . Any such risk-sharing would be economically suspect in the absence of increased coordination of activities. Examples might be found in industries in which competing firms independently adopt a new input into their manufacturing process in the hopes that the new input reflects "the future" of the industry. Such an input might include a 


\section{The Line $(\mathrm{X}, \mathrm{Y})=0$ to $(\mathrm{X}, \mathrm{Y}) \rightarrow \infty$ : Perfect Competition to Single Entity}

The graph in Figure 1 reflects a 45-degree line extending from $(\mathrm{X}, \mathrm{Y})=0$ to $(\mathrm{X}, \mathrm{Y}) \rightarrow \infty$. At a high level of generalization, that line divides conduct that is likely to be a section 1 violation from conduct that is unlikely to present an antitrust concern. All conduct that is illegal per se or subject to a quick look rule of reason analysis lies significantly below and to the right of the line. All conduct undertaken by a single entity, which is therefore immune from antitrust scrutiny, lies above and to the left of the line.

Conduct that lies near this line is ambiguous as to its antitrust treatment. It is subject to the rule of reason, reflecting the existence of both (1) potential competitive harm and (2) potential efficiency benefits. As conduct deviates from the line to the upward and leftward, there is a greater degree of risksharing and a lesser degree of coordination. As the efficiency incentives of risk-sharing increasingly overbear the potential for competitive harm from coordination, conduct moves into an antitrust safety zone. A non-sharing economy example of conduct that would diagram to the upper left of the line is standard-setting behavior. Firms may coordinate on conduct

new technology, such as electric power in automobiles or touch screens in smartphones. It might include a new manufacturing process, such as robotics. Or it might include a new location, such as restaurants and shops that make bets on a community's future economic development. These examples of investment based on independent hope, which happens to be shared among many, reflect the closest approximations of risk-sharing without coordination among the participants. Of course, in all of these examples, coordination may exist. Technology adoption can occur through standard-setting and joint research and development; manufacturing processes can be the subject of trade association discussions; investments in geography can be incentivized by states or localities seeking to encourage local development. The lightly shaded triangle in the upper left corner of Figure 1 reflects the extreme unlikelihood of complete sharing of profits and losses among individuals or atomistic firms without coordination of their activities. This would be a hypothetical single firm that fails to engage in coordination among its constituent parts. A firm in that triangle would be engaged in compete risk-sharing with no coordination. It is likely that any such firm would not exist for long. 
that is highly competitively sensitive, like a decision to cease competing on innovation, but because standard setting reflects a joint commitment to the success of the standard, it reflects motion upward on the $\mathrm{Y}$-axis and is generally permitted by antitrust law. 224

As conduct deviates from the line to the downward and rightward, there is a lesser degree of risk-sharing and a greater degree of coordination. This presents increased concern for harm to competition outweighing the efficiency incentives of risk-sharing. A non-sharing economy example of conduct to the lower right side of the line is an agreement among credit card issuers not to compete against their joint venture card network by entering into agreements with a third party card network. 225 Such an agreement is not illegal per se, because it does not reflect an agreement on matters of extreme competitive sensitivity, but it does reflect coordination in excess of the risk-sharing among the parties to the agreement.

The direction of the line demonstrates that as risk-sharing increases, the degree of coordination among constituent parts of an enterprise that will be tolerated also increases. At the extreme end where $(\mathrm{X}, \mathrm{Y})$ approaches infinity, a single firm may engage in the same conduct that would be illegal per se were it engaged in by a set of competitors.

\section{B. Graphing Exemplar Sharing Economy Enterprises}

Sharing economy enterprises like TaskRabbit involve little more than fees paid for matching services and back-office support, facilitating transactions between providers and consumers. In the absence of agreements on competitively sensitive transaction terms, these enterprises easily survive a rule of reason inquiry. Platforms like Uber and Lyft control many of the transaction terms including price, which is commonly considered the most competitively sensitive term. As shown

224 See 15 U.S.C. $\S 4302$ (dictating that the rule of reason standard applies to "standards development organization[s]").

225 See United States v. Visa U.S.A., Inc., 344 F.3d 229, 242 (2d Cir. 2003). 
above, these enterprises warrant quick look scrutiny under section 1.226

Sharing economy enterprises in between those extremes are subject to the section 1 rule of reason, an "enquiry meet for the case." 227 Justice Souter's phrase reflects the reality that the rule of reason is a sliding scale, where the more competitively sensitive the contract terms involved, the greater the attention paid to the enterprise. With Uber and TaskRabbit as the extremes, it is possible to assess the sharing economy enterprise structure in relative terms. The closer in form to Uber, the more searching the rule of reason analysis. For instance, Lyft (with its established, but alterable, price terms) is close to Uber-level scrutiny, while Airbnb (with its minimal control over transaction terms) is closer to the hands-off approach accorded to TaskRabbit. This rule of reason inquiry, a

226 It helps to reproduce here Table 1 from Part II of this Article. See supra Part II, at 13.

\begin{tabular}{|c|c|c|c|c|c|}
\hline Table 1 (reproduced) & Uber & Lyft & $\mathrm{ABB}$ & $\mathrm{CS}$ & TR \\
\hline $\begin{array}{l}\text { Establishes a price for the service } \\
\text { or product provided }\end{array}$ & $\mathrm{X}$ & $\mathrm{X}$ & & $\mathrm{X}$ & \\
\hline $\begin{array}{l}\text { Controls the method of payment } \\
\text { over the platform }\end{array}$ & $\mathrm{X}$ & $\mathrm{X}$ & $\mathrm{X}$ & & $\mathrm{X}$ \\
\hline $\begin{array}{l}\text { Maintains a functionality for prod- } \\
\text { uct or service reviews }\end{array}$ & $\mathrm{X}$ & $\mathrm{X}$ & $\mathrm{X}$ & $\mathrm{X}$ & $\mathrm{X}$ \\
\hline $\begin{array}{l}\text { Sets minimum requirements for } \\
\text { the supplier's personal or real } \\
\text { property used in the transaction }\end{array}$ & $\mathrm{X}$ & & & & \\
\hline $\begin{array}{l}\text { Sets requirements meant to en- } \\
\text { sure compliance with accessibility } \\
\text { and other civil rights laws }\end{array}$ & $\mathrm{X}$ & & & & \\
\hline $\begin{array}{l}\text { Disclaims control over suppliers, } \\
\text { including their manner of perform- } \\
\text { ing a service or providing a prod- } \\
\text { uct }\end{array}$ & $\mathrm{X}$ & $\mathrm{X}$ & & & \\
\hline $\begin{array}{l}\text { Collects taxes imposed by a partic- } \\
\text { ular locality }\end{array}$ & & & $\mathrm{X}$ & & \\
\hline $\begin{array}{l}\text { Ensures that realistic alternative } \\
\text { means exist for suppliers to reach } \\
\text { consumers }\end{array}$ & & & $\mathrm{X}$ & & $\mathrm{X}$ \\
\hline
\end{tabular}

227 Cal. Dental Ass'n v. FTC, 526 U.S. 756, 781 (1999). 
matter of degree rather than a categorical distinction, requires substantial judicial inquiry into the competitive sensitivity of the subject of the agreement.

However, this is only half of the analysis. In Part III, the Article also shows that a single firm may engage internally in a broad range of agreements on the most competitively sensitive terms without even having its behavior assessed under section 1.228 By definition, sharing economy enterprises are not single entities. 229 The limits of the Coasean definition of a firm in a world of hyper-efficient transactions, described in Part II, suggest that the doctrinal single entity analysis is not sufficiently nuanced. This Article therefore treats the single entity concept in a sharing economy enterprise as an "enquiry meet for the case," rather than a binary distinction. 230 After judging the competitive sensitivity of a particular set of coordinating agreements defining an enterprise, it is necessary to judge the degree of risk-sharing among the suppliers. At the extreme of risk-sharing, if, for example, an enterprise is determined actually to employ its suppliers, the enterprise becomes a single firm and is immune from scrutiny. Short of single entity treatment, high levels of risk-sharing justify high levels of coordination.

The antitrust treatment of sharing economy enterprises becomes apparent when they are placed on the Figure 1 graph on the basis of (1) the extent and nature of the coordination among the constituent parts of the enterprise and (2) the degree of risk-sharing involved in the enterprise. Using Figure 2 , below, to depict these relationships, this Subpart considers the placement of the leading examples from Part II and what that means for their antitrust treatment. These examples include:

228 See supra Part III.

229 See supra Part II.

230 The traditional single entity analysis is binary, turning on the sharing of profits and losses or lack thereof. See Anderson, supra note 213, at $527-28$. 
- Uber (and Lyft);

- Airbnb (and Couchsurfing); and

- Task Rabbit.

Location on the graph is an imprecise determination. However, Figure 2, below, reflects likely placements for these examples. The remainder of this Subpart explains this judgment with respect to each firm.

\section{FigURE 2: PLATFORM PLACEMENT ON RISK-SHARING/ COORDINATION GRAPH}

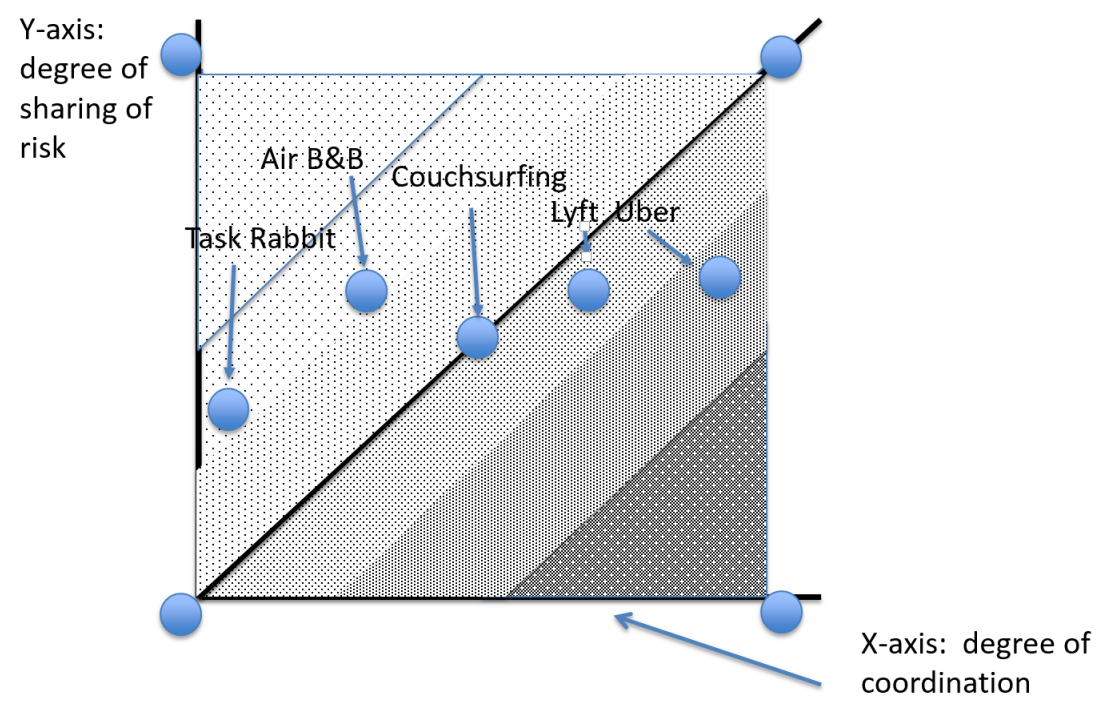

\section{TaskRabbit}

TaskRabbit is a sharing economy enterprise that exists well in the antitrust safety zone because of the near lack of coordination among its suppliers. Table 1231 shows coordination on only two factors: the manner of making payment and the collection and dissemination of reviews of quality and reliability for the participants on the platform. Neither present serious competitive concerns. For example, if two plumbers (suppliers of services of the sort marketed through the TaskRabbit platform) reached an agreement to create a joint

231 Table 1, supra note 226. 
venture to process payments or to advertise their respective consumer satisfaction, the rule of reason scrutiny would be minimal. Operating through the TaskRabbit platform adds efficiency to any such coordination while in no way adding to the competitive concern. The TaskRabbit enterprise therefore maps to a low point on the X-axis, below all of the other examples and nearly in the zone of antitrust irrelevance. 232

\section{Uber}

Uber presents the greatest concern for coordination and lowest likelihood of efficiency produced by risk-sharing among the constituent parts of the enterprise. Coordination in the case of Uber occurs on a matter of maximum sensitivity-the price charged for the services provided. Uber's coordinating conduct is so concerning that it would be per se illegal price fixing if there was no risk-sharing.

Using the coordination versus risk-sharing paradigm, the Uber enterprise escapes such per se condemnation because of the degree of risk-sharing among the drivers. Suppliers on the Uber platform are mutually invested in the platform's success, without which they are individually unable to produce a taxi like service that is appealing to consumers. That is for at least three reasons. First, in the absence of the platform, which in turn can only exist at substantial scale, suppliers do not have a realistic means of matching their services with the demand for one-off ride hailing. ${ }^{233}$ Second, the platform, operating at scale, permits the creation of reliable reputations through op-

232 The TaskRabbit enterprise also maps to a relatively low Y. TaskRabbit suppliers operate in industries that are traditionally populated by small firms or sole proprietorships. Plumbers, painters, builders, and handymen frequently market their services on an individual basis, using traditional marketing channels. In most cases, TaskRabbit likely serves as little more than an additional marketing channel and an efficient payments provider. The platform's success or lack thereof is likely not sufficiently meaningful to affect the success, or lack thereof, of its suppliers.

233 Less successful examples of unregulated taxi service include appealing to arriving passengers at airports. Those efforts fail to produce a meaningful market for unregulated taxis. 
portunities to rate suppliers. Third, the platform permits regulatory disruption by achieving sufficient scale and public appeal to discourage its being subjected to potentially harmful regulatory interference.

Uber drivers are strongly invested in the success of the enterprise, a degree of risk-sharing that should move the enterprise far enough along the $\mathrm{Y}$-axis to escape per se condemnation. Under a quick look rule of reason analysis, the Uber enterprise would be required to show the benefits to competition stemming from its enterprise structure before a plaintiff would be required to show net harm. This conclusion is consistent with the classical approach to analyzing Uber, described in Part IV, with one analytical difference. Under the classical approach, Uber's procompetitive argument would hinge on the logical nexus between the price identity agreement and the efficiency of the Uber operating model.234 Under the approach suggested here, Uber's procompetitive argument would be that the competitively sensitive level of coordination is justified by the likelihood of efficiencies incentivized by the level of mutual risk-sharing. ${ }^{235}$

234 See supra text accompanying notes 195-202.

235 Lyft follows a similar business model to Uber. However, there has historically been an important difference: the Lyft app explicitly permits tipping. Tipping permits price negotiation above an established floor. Uber's move to add a tipping function to its app eliminates this disparity going forward. In the presence of tipping, the apps increase competition among drivers for consumer dollars above the price floor. However, a tipping option does not eliminate the competitive concern. In the absence of risk-sharing, the Lyft agreement would still be treated as illegal per se. The pricing variability tipping introduces merely moves Lyft closer to zero on the X-axis. Lyft takes advantage of the precise risk-sharing that the Uber enterprise involves: suppliers are invested in the enterprise's success. The Lyft enterprise is subject to rule of reason treatment, likely less "quick" than its competitor Uber. It is possible that a plaintiff challenging the Lyft agreement under section 1 will need to show an upward effect on prices before Lyft would bear the obligation to demonstrate the efficiencies flowing from the enterprise structure. 


\section{Airbnb}

Airbnb maps to the lightly shaded "safety zone" on Figure 2 . This reflects the reality that the coordination in the case of Airbnb is largely limited to matters that are not competitively sensitive. These include the manner of advertising, manner of collecting payment, and requirements agreed to by service providers on the Airbnb platform including insurance and liability for loss. The X-axis location for Airbnb is substantially lower than that for either Uber or Lyft, both of which include agreements on price, the matter of primary competitive significance. An agreement among competitor lodging servicesfor example, between the hotel chains Hilton and Sheratonto jointly advertise or create a billing and collections service organization would be subject to full blown rule of reason treatment. Under that approach, the plaintiff would not be able to quickly shift the burden to the defendant to present a procompetitive justification.

Determining the appropriate antitrust treatment for Airbnb also requires a consideration of the degree of risk-sharing among the suppliers on the platform. Airbnb suppliers are invested in the platform to a degree similar to Uber and Lyft suppliers. Like Uber drivers, Airbnb suppliers have alternate means to market their properties, including word of mouth, local rental agencies, and early-mover Vacation Rentals by Owner, a platform not unlike Airbnb but less aggressive in expansion and less effective in moving to mobile technology. ${ }^{236}$ Airbnb suppliers also depend heavily on reliability ratings, not unlike Uber suppliers, for whom consumer trust is paramount. The regulatory disruption benefit of the platform is nearly a precise match to Uber; only at sufficient scale and public investment in the platform can Airbnb avoid potentially crippling regulatory interference in its operations. Holding $\mathrm{Y}$ constant between the two firms, but decreasing $\mathrm{X}$ to reflect non-sensitive matters of coordination in the case of

236 See VACATION RENTALS BY OWNER, http://www.vrbo.com [perma.cc/FH4R-SFZG]. 
Airbnb, moves the enterprise to the lightly shaded "safety zone."237

\section{Summary}

This Part states a more nuanced approach to determining how section 1 should be applied to a particular sharing economy enterprise. Drawing on the understanding that the sharing economy enterprise disrupts the Coasean firm, Part V treats the question of whether an enterprise is a single entity, and thus achieves the efficiencies of integration, as a sliding scale from minimal risk-sharing to complete sharing of profits

237 Lesser known competitor "Couchsurfing" is a scaled back version of Airbnb that allows comparable variability in listings. As distinct from Airbnb, however, Couchsurfing imposes an agreed maximum price, set at zero. Neither consumers nor suppliers may negotiate transaction terms that involve an exchange of money for lodging. Intuition suggests that the only effect of a zero price is to maintain prices lower than in its absence. However, antitrust law is clear that horizontally agreed maximum prices are as pernicious as horizontally agreed minimum prices. Both interfere with the price setting mechanisms of the free market by preventing individually negotiated transaction terms. As illustrations of the possible harm from the Couchsurfing agreement, the effect of a zero price may be to discourage quality improvements for which consumers of Couchsurfing services would gladly pay. It may discourage would-be competitors from joining the platform or even forming a competing platform, with the effect of reducing the quantity of lodging services supplied. This counterintuitive result may suggest a more comprehensive rethinking of section 1 standards as applied to sharing economy firms. Couchsurfing suppliers are less coordinated on other aspects of their providing services. The terms of service do not involve a centralized payment mechanism. The zero-price agreement does not necessarily mean there could be no centralized payment system. Couchsurfing could take credit cards for damage deposits or as a means to improve reliability ratings. They do not involve tax collection services. In sum, Couchsurfing involves an agreement on a highly sensitive transaction term, the price, but avoids agreement on a number of other transaction terms. It maps on the X-axis to a point above Airbnb but below Uber and Lyft. On the Y-axis, Couchsurfing maps below previous examples. The value of reliability rankings and matching services is consistent with Airbnb and, like Airbnb, possibly greater than Uber and Lyft. The regulatory disruption value of the platform, protecting its suppliers from regulatory interference, is not an issue in a fee-free arrangement. 
and losses. Mapping sharing economy enterprises to the appropriate point on the Y-axis is one step in the analysis. The second step is to map the enterprises to the $\mathrm{X}$-axis, based on the extent and competitive sensitivity of the coordination they impose. This analysis offers the promise of broad application across the sharing economy.

\section{CONCLUSION}

This Article tackles the challenge of applying antitrust law, now more than 125 years old, to the most modern of enterprise structures-the sharing economy enterprise. The difficulty is not small, as traditional concepts such as horizontal versus vertical agreements and single entity versus combinations of separate entities do not map well to the sharing economy. And this difficulty is not merely hypothetical. Current litigation challenging the most well-known sharing economy firm, Uber, has the potential to be momentous in nature. The court has already held that the plaintiffs pleaded a horizontal agreement. If the court were to decide that this agreement was illegal per se, Uber would be forced to make a meaningful alteration to its basic structure. Alternatively, if the court were to decide that the agreement was subject to the quick look rule of reason, Uber would be charged with the burden of demonstrating meaningful procompetitive benefits and the relevance of the complained-of pricing term to those benefits.

This Article also shows that every sharing economy enterprise has terms of service that might, in theory, be challenged as a violation of section 1 of the Sherman Act. While not all of these terms approach the competitive sensitivity of an agreed price term, many, including those that specify the methods of payment or the type and quality of the products or services provided, do reflect agreements on matters that directly affect consumer choice and welfare. However, these terms of service enable sharing economy enterprises to succeed. They allow consumers to form expectations about what they are buying and how much it will cost-just like buying from a traditional business firm-while benefiting from a large set of small suppliers. The interaction between these consumers and small 
suppliers is made possible only by the sharing economy enterprise.

This Article advocates accommodating the innovative structure of the sharing economy enterprise by altering antitrust analysis. Courts should assess the degree to which constituent parts of sharing economy enterprises (1) share economic risk and (2) coordinate their behavior on competitively sensitive matters. Charting the degree of risk-sharing in relation to the degree of coordination on competitively sensitive matters permits a determination of the appropriate antitrust treatment. The process advocated here is more appropriate to the disruptive enterprise structure that defines the sharing economy. 